\title{
Leadership Dimensions Influencing Sustainability Leadership in Sri Lanka: Mediating Effect of Managers' Ethical Behaviour and Organizational Change
}

\author{
Ayoma Sumanasiri ${ }^{1}$ \\ ${ }^{1}$ Department of Commerce, Faculty of Management Studies and Commerce, University of Sri Jayewardenepura, \\ Gangodawilla, Nugegoda, Sri Lanka \\ Correspondence: Ayoma Sumanasiri, Department of Commerce, Faculty of Management Studies and Commerce, \\ University of Sri Jayewardenepura, Gangodawilla, Nugegoda, Sri Lanka. E-mail: ayoma@sjp.ac.lk
}

Received: March 2, $2020 \quad$ Accepted: April 2, $2020 \quad$ Online Published: April 6, 2020

doi:10.5539/jms.v10n1p113 URL: https://doi.org/10.5539/jms.v10n1p113

\begin{abstract}
This study examines the mediation effect of managers' ethical behaviour and organizational change on the leadership dimensions that influence sustainability leadership among Sri Lankan managers. Manager's attitudes to organizational change and their ethical behaviour are identified as essential dimensions to achieve sustainable leadership in the business world. While much of the literature underlines the direct relationship between organizational leadership and either organizational change or manager's ethical behaviour, only a few studies focus on the mediating effect of the manager's ethical behaviour and organizational change leadership on perceptions of creating a sustainable organization. Sri Lanka is identified as a developing country with strong socio-cultural values that promote sustainability. Understanding what constitutes sustainability leadership in a developing country such as Sri Lanka is worth examining. The responses of 596 managers were analyzed using factor analysis and structural equation modeling. The findings confirm that stakeholder relations are the most influential dimension for creating sustainability leadership. Mediation analysis tests confirmed that the two mediators of managers' ethical behaviour and change leadership fully mediate the relationships between employee engagement and leaders' concern for social and environmental sustainability, which concern was identified as the weakest of the three leadership dimensions suggesting that long-term orientation has not much potential for creating sustainability leadership among Sri Lankan managers.
\end{abstract}

Keywords: sustainability leadership, leadership behaviours, cultural modeling, developing economies

\section{Introduction}

Sustainability issues are common to all countries regardless of their level of economic, social and environmental development (UN, 2015). Unlike the developed world, developing countries are largely exposed to diverse, complex and major issues of environmental pollution, poverty and gender discrimination, etc. The concept of corporate sustainability has been explored in depth mainly in the developed world but is little known in the developing countries (Kantabutra \& Avery, 2012; Kantabutra \& Saratun, 2013), suggesting that today sustainability has become a key managerial task for ensuring organizational sustainability.

The literature defines a sustainable leader as one who aims to minimize the negative impact of managerial decisions on the triple bottom line (i.e., the environment, economy and society). Managers need outstanding leadership skills to address issues surrounding organizational sustainability so as to minimize the negative impacts on the triple bottom line (Metcalf \& Benn, 2013).

Researchers and practitioners such as Avery and Bergsteiner, (2010, 2011); Dunphy and Benn, (2013) and Parkin, (2010) point out that strong leadership that perceives sustainability matters create sustainability in organizations. Leadership scholars argue that leadership theories such as charismatic leadership, transformational leadership, ethical leadership, spiritual leadership, responsible leadership, servant leadership and environmental leadership contribute to organizational sustainability and even help organizations to gain competitive advantage in the industry (Avery \& Bergsteiner, 2010, 2011). Remarkably, those organizations that disregard sustainability have faced corporate scandals and even bankruptcy.

Organizational transition towards sustainability often requires its leaders to be more innovative in managing 
planned organizational changes (D'Amato \& Roome, 2009; Gilbert, 2019; Hargett \& Williams, 2009; Strategic Direction, 2011; Willard, 2009). Excellent leadership that prioritizes sustainability is considered an important aspect when directing organizational change towards sustainability (Dunphy \& Benn, 2013; Dunphy, Griffiths, \& Benn, 2014), which confirms the essentiality of change-oriented leadership skills to achieve organizational sustainability (Akins, Bright, Brunson, \& Wortham, 2013; Avery \& Bergsteiner, 2011; Bossink, 2007; Gilbert, 2019; Millar, Hind, \& Magala, 2012).

\subsection{Research Problem}

Although much of the literature underlines the direct relationship between organizational leadership and either organizational change or ethical behaviour, only a few studies focus on the mediating effect of the manager's ethical behaviour and organizational change leadership on perceptions of creating a sustainable organization.

In order to explore this issue further the present study examines the mediating effect of the two identified mediating variables (i.e., leader's commitment to organizational change and ethical behaviour) on the perceptions of sustainable leadership in Sri Lankan organizations. To achieve this research objective the following research questions were developed:

(1) How does the leaders' commitment to organizational change mediate the relationship between the three leadership dimensions (EMP, LONG and STK) and sustainability leadership dimensions? and

(2) How does the leaders' ethical behaviour mediate the relationship between the three leadership dimensions (EMP, LONG and STK) and sustainability leadership dimensions?

To examine the managerial perceptions of sustainability leadership in Sri Lankan organizations it is important to examine the context-specific factors that influence the leader's attitudes, behaviours and perceptions. By doing so, this study seeks to find perceptions of organizational leadership in the developing world from the sustainability perspective.

Sustainability leadership in organizations has attracted attention in the developing world more than in the developed world as the former faces more unique and diverse challenges (Khavul \& Bruton, 2013; Selvarajah, Meyer, Jayakody, \& Sukunesan, 2020). Most organizations in the developing world aim to maximize short-term profit compared with businesses in developed countries (Bin, 2020; Karande, Rao, \& Singhapakdi, 2002). Hence, understanding and incorporating context-specific values and beliefs help managers to include them in their sustainability strategies (Edjossan-Sossou, Galvez, Deck, Al Heib, Verdel, Dupont, \& Morel, 2020; Khavul \& Bruton, 2013).

\section{Literature Review}

Similar to the effective leadership behaviours developed by Yukl (2012), a group of East Asian researchers (Selvarajah, Duignan, Suppiah, Lane, \& Nuttman, 1995) has developed a similar leadership concept called "excellence in leadership" to understand the perceptions of leadership behaviours in different cultural contexts. This concept enables researchers to explain how organizational leaders in a particular culture perceive an excellent leader within their organizations. To achieve this objective, Selvarajah et al. (1995) developed 94 leadership behavioural statements in the APEL questionnaire.

In order to examine Sri Lankan managers' perceptions of sustainability leadership, this study first explored the sustainability leadership literature pertaining to Sri Lanka and identified five excellent leadership dimensions that influence sustainability leadership among Sri Lankan managers: concern for employees (EMP), stakeholder relationships (STK), and long-term orientation (LONG), which were identified as variables with a direct impact on sustainability leadership while leaders' ethical behaviour (SUSTHINK) and change leadership CHNG) were identified as mediating variables.

\subsection{Context-Specific Nature of Sustainability Leadership}

Traditionally, the leadership literature considers organizational leadership to be a universal phenomenon (Bass, 1990; Bass \& Avolio, 1993; Fahr, Podsakoff, \& Cbeng, 1987; Murdoch, 1967; Wakabayashi \& Green, 1984). Most of the previous leadership literature is biased towards America, which caused Wijewardena and Wimalasiri, (1996) and Peterson and Hunt (1997) to criticize the inadequacy of Western-based leadership theories to explore diverse organizational leadership characteristics of non-Western cultures. In a globalised market, awareness of diverse cultural values helps leaders to make optimal decisions that match the local context (Javidan \& House, 2001; Scanduraa \& Dorfman, 2004; Triandis, 1995). The importance of local cultural values was deemed important in some of the early studies such as Parson's (1951). Those organizations that accept cultural diversity are always able to outperform their counterparts (Avery \& Bergsteiner, 2010, 2011). Hence, the leader's 
knowledge of diverse cultural values in the local market will create excellent leadership that has a minimum impact on the triple bottom line (Avery \& Bergsteiner, 2011; Hargett \& Williams, 2009; Khavul \& Bruton, 2013; Selvarajah et al., 2020).

This gave rise to the urgency to identify diverse leadership styles across cultures (Hofstede, 1986; Hofstede \& Bond, 1988; House et al., 1999; House \& Javidan, 2004) and to re-examine the concepts surrounding leadership and accept the influence of diverse cultural values, beliefs and behaviours. Following this line, researchers such as Laurent (1986) began to examine the perception of leadership as a culture-specific concept in order to explore leadership as a culture-specific concept. Moving further, Selvarajah, Meyer and Davuth (2012), Selvarajah, Meyer and Donovan (2013) and Selvarajah et al. (2020) used the cognitive approach to explain the influence of cultural values, norms, attitudes and beliefs on diverse leadership behaviours in different cultural contexts. Following the cultural context perspective in examining leadership, Dunphy and Benn (2013); Hargett and Williams (2009) and Selvarajah et al. (2020) explored context-specific factors that influence sustainability in a particular culture. The model and the leadership behavioural statements used to develop this study were also tested in different cultures (Selvarajah, Meyer, \& Donovan, 2013; Selvarajah et al., 2020) and confirmed as successful in examining managerial leadership in different contexts.

\subsection{Context of the Study}

The selection of a Sri Lankan managerial sample was theoretically important because most research on leadership has focused on Western cultures (House \& Aditya, 1997), and there is a growing demand for leadership studies in non-Western and culturally diverse contexts (Bass, 1990; Hamlin \& Patel, 2020). Sri Lanka has often been described as a developing economy after recently emerging from 30 years of civil war-a nation that is now poised to accelerate its economic development in a sustainable manner (Central Bank of Sri Lanka, 2018; Gunarathne, De Alwis, \& Alahakoon, 2020). However, Sri Lanka still faces several diverse challenges such as corruption, environmental pollution and regionally balanced economic development, in its way forward to achieving sustainable economic performance (Geekiyanage \& Vithanage, 2015; Gunarathne et al., 2020; Ministry of Environment, 2012). Thus, developing a sustainability leadership model as done in this study has significance for managers in a complex business environment such as Sri Lanka. Developing a sustainability leadership model will allow researchers and practitioners to identify sustainable managerial skills, behaviours and capacities to facilitate the development of sustainability leadership efforts in Sri Lanka's industrialization process. As the sustainability of business has now become an important aspect in the Sri Lankan organizational context, Sri Lankan managers were considered suitable respondents for this study.

\subsection{Independent Variables Measuring Leadership Dimensions}

The following literature review explains how leadership dimensions relating to stakeholder relationships (STK), long-term perspective (LONG) and concern for employees (EMP) can become an essential component in achieving sustainability leadership.

\subsubsection{Stakeholder Relationship}

Society consists of complex and interrelated networks with diverse stakeholders where leadership is responsible for ensuring unity and harmony within society (Salem, 2012; Ghassim \& Foss, 2020). The stakeholder perspective has often been identified as a core strategic leadership competency (Donaldson \& Preston, 1995; Polansky, 1995; Porter \& Kramer, 2006; Post et al., 2002; Wondirad, Tolkach, \& King, 2020). Strong stakeholder relationships help managers to maximize the longevity of business success (Avery \& Bergsteiner, 2011; Murphy, 2002; Post, Preston, \& Sachs, 2002) and even improve innovation and marketing ability (Löfsten, Klofsten, \& Cadorin, 2020; Sohal, Gordon, Fuller, \& Simon, 1999).

Historically, Sri Lankan society has been a patriarchal one (Hewage, Teicher, Alam, \& VanGramberg, 2008; Kamalika, 2008; Nanayakkara, 1999). Its patrimonial and feudal elements, a caste-based social structure, and religious institutions have all played a role in the pre-colonial Sri Lankan social system (Hewage et al., 2008), and its hierarchical structure with a high power distance (Liyanage, 1996b) confirms that Sri Lankan society is still often characterized by inequality in the distribution of power and authority between the social classes and even within the workplace (Chandrakumara \& Sparrow, 2004). Sri Lankan corporate culture shows clear disparity in the distribution of power between managers and non-managers (Hewage, 2011), where it is commonly observed that managers dominate their subordinates, subordinates are afraid to disagree with their managers, managerial decision-making is autocratic, and leadership behaviours are paternalistic (Nanayakkara, 1999). Some popular Japanese management practices that promote team work are also common in contemporary Sri Lankan organizations (Hewage, 2011; Wickramasinghe, Hopper, \& Rathnasiri, 2004). 


\subsubsection{Long-Term Perspective}

In Sri Lankan society, parents often expect their children to seek permission for even minor tasks in the belief that their children's wisdom and experience will develop under their supervision as they mature with age (Liyanage, 1996a). This is also common in the Sri Lankan organizational context where subordinates expect their managers' support as they respect the authority and status of managers (Liyanage, 1996a). In addition, most Asian managers respect rank, expect status recognition in social situations, treat managers as ritual personalities and courtesies are consistently observed by most of the Asian management (Wijewardena \& Wimalasiri, 1996). Edirisinghe (2008) also found that most corporate-level bank managers are responsible for competitive, supplier, economic and political analysis while marketing managers are mostly responsible for customer analysis, and operational managers for technological analysis. Sri Lankan culture, which is identified as femininity-oriented (Hewamanne, 2020), seems to be reflected through many Sri Lankan managers who demonstrate such femininity values in their daily decision-making while their subordinates often establish a patriarchal relationship with their supervisors (Liyanage 1996a).

\subsubsection{Concern for Employees}

Most Asian managers maintain close employee relationships and are more group-oriented than their Western counterparts (Wijewardena \& Wimalasiri, 1996). From pre-colonial Sri Lankan society, major decisions relating to trade were based on common agreement between community leaders and villagers reflecting the collectivistic values of Sri Lankan people which these values are still observable within the contemporary Sri Lankan working class (Hewage et al., 2008). Often, Sri Lankan managers take care of their subordinates as if they were their children, creating a relationship as of a father looking after his children (Liyanage, 1996a). This creates a working family along different levels in the organizational hierarchy and strong group participation. The manager's relationship with employees also influences their performance appraisal (Jayawardana, O'Donnell, \& Jayakody, 2013). Sri Lankan managers often arrange annual staff trips, award ceremonies and other socio-cultural events to motivate employees (Hewage, 2011). Therefore, Sri Lankan managers perceive employee unions as a powerful force that can have a strong influence on their business decisions (Hewage, 2011).

\subsection{Dependent Variables in Measuring Sustainability Leadership}

There are three dimensions that explain the sustainability leadership of Sri Lankan managers, namely, leader's concern for "excellence in leadership" (EXL), "firm's financial performance" (FIN) and "social and environment performance" (ENV). EXL aims to identify the combination of excellent leadership behaviours that are desirable for good leadership by surpassing others in a particular organization (Selvarajah \& Meyer, 2008; Selvarajah et al., 2020). The Asian perspectives of the leadership (APEL) model developed by Selvarajah, Dulgan, Suppiah, Lane, and Nuttman (1995) have since been used on many occasions (for example, Selvarajah, 2008; Selvarajah \& Meyer, 2006, 2008; Selvarajah et al., 2012; Selvarajah et al., 2020) to examine the leadership perceptions of managers across different industries, countries and societies. ENV aims to identify perceptions of excellent leadership behaviours that are important for the welfare of society and the protection of natural resources. FIN aims to identify the perceptions of excellent leadership behaviours important for the healthy financial performance of the organization.

\subsection{Mediating Variables and Hypotheses}

\subsubsection{Leader's Commitment to Change}

Organizational change has often been highlighted as an essential dimension of sustainability (Avery \& Bergsteiner, 2010; Dunphy \& Benn, 2013; Dunphy et al., 2014; Gilbert, 2019). Organisations that respond through change improve their comptitiveness and maximise stakeholder wealth (Dunphy et al., 2014). For this purpose, organisations need change leaders rather than change managers to drive organisations towards success (Caldwell, 2003). The developing nations face enourmous challenges relating to sustainability (Ovadje, 2014). The lack of change leadership skills in the developing countries impede organisational transformation into sustainability. In Sri Lanka, most managers have few innovative skills, entrepreneurial attitutudes and readiness to accept risk, resulting in negative attitudes to organisational change (Wickramasinghe et al., 2004). Also, in the Sri Lankan context, changes in international management practices, rising oil prices and living costs, shrinking demand for the country's exports, heavy reliance on imports, and the lag in its economic development (Central Bank of Sri Lanka, 2018) are influencing Sri Lankan managers to change their businesses as a usual means to compete internationally. Hence, this study identifies leader's commitment to change as a mediating variable to achieve sustainable leadership. 


\subsubsection{Manager's Ethical Behaviour}

Manager's ethical thinking for maintaining trustworthy and responsible relations would create sustainability leadership (Doppelt, 2012). In Sri Lanka rewards and recognition for lower-performing managers are often inadequate; so, subordinates tend to maintain an economic relationship (transactional leadership) rather than social engagement (transformational leadership) with their senior management (Jayawardana, O'Donnell, \& Jayakody, 2013). Sri Lankan managers care for their employees and think of their employees' work-life balance and welfare facilities (Abeysekera, 2007). The present managers of Sri Lankan organizations reflect both colonial Western business practices such as profit maximization, productivity, efficiency, competition, and risk management and Asian values such as loyalty, trust, cooperation, compassion, tolerance, morality and empathy thus creating a new breed of Asian managers (Wijewardena \& Wimalasiri, 1996). The 30-year war between the LTTE and the Sri Lankan Government has meant that many Sri Lankan youths of that war-torn period grew up being suspicious, fearful and mistrustful of each other (UNDP, 2019). Most Sri Lankan employees expect their managers to be exemplary in character and to follow good practices even in their personal lives resulting in most Asian managers maintaining good personal relations with their subordinates (Wijewardena \& Wimalasiri, 1996). They would like to offer long-term training opportunities and promotions and other career opportunities to their employees to advance up the organization's career ladder compared to managers in Western societies (Wijewardena \& Wimalasiri, 1996). These attitudes have made Asian managers reluctant to lay off employees, preferring to maintain a moderately high level of job security compared with Western organizations (Wijewardena \& Wimalasiri, 1996). Most young Sri Lankans believe that traditional social values such as ethnocentrism, power distance between different levels in the hierarchy, and the male-dominant cultural values of Sri Lankan society are inappropriate and are barriers to social harmony (UNDP, 2019). Supporting this, both the traditional and Western education systems in Sri Lanka have promoted environmental protection attitudes among new generations to come (United Nations Educational Scientific and Cultural Organization, 2018).

Based on the above literature in total there were 18 hypotheses (Appendices 1 and 2) developed to test the relationship between the three independent variables and the three dependent variables and the two mediating variables.

\section{Research Methodology}

Sustainability leadership has been mainly examined in qualitative research studies done in Western cultures or economically developed nations paving the way for this study to use a deductive-quantitative approach supported by prior logical reasoning based on previous qualitative research. In developing the model, the existing sustainability leadership models were explored and modified to suit the sustainability dimensions of the social, political, economic and cultural contexts of Sri Lanka.

The respondents in this study are practicing full-time managers across different demographic profiles in Sri Lanka. As many as 1632 questionnaires were distributed, of which 821 were returned and of which 596 questionnaires were used for further analysis.

The final sample consisted of $88.4 \%$ Sinhalese, $8.1 \%$ Tamils, and 3.5\% Burghers and other ethnic groups. The majority of the sample ( $80 \%$ ) were Buddhists, $10 \%$ Christians, $6 \%$ Hindu, $3.2 \%$ were Islamic and $0.8 \%$ of other religions. Males formed $69 \%$ of the sample $31 \%$ and females $31 \%$. Of the respondents $60 \%$ were below 35 years with the majority of the respondents, $48 \%$, having less than five years of managerial experience. $72 \%$ of the respondents were employed in the private sector while $28 \%$ worked in the public sector.

\subsection{Measures of Leadership Behavior}

The data were gathered using a questionnaire developed in English, and a Likert-type scale was used to measure leadership behavioural aspects. As a basis, 94 leadership behavioural items (Selvarajah et al., 1995) were used to measure eight variables in the model while nine items in the ENV variable were self-developed with the support of literature such as Kalshoven, Den Hartog and De Hoogh (2011) and three items in the FIN were self-developed using the support of the Global Reporting Initiative (2016). Statistical tests, namely, exploratory factor analysis (EFA), confirmatory factor analysis (CFA), and structural equation modeling (SEM) techniques based on SPSS and AMOS software (Hinkin, 1998) were used to analyze the data.

\section{Results}

The sample was split into two independent samples using the random split sample option in SPSS (Joreskog, 1993; Hinkin, 1998). The first sample consisted of 120 responses (calibration sample) and was used for EFA. The second independent sample (validation sample) consisted of 476 responses and was used for CFA. 


\subsection{EFA Results}

Appendices 3 and 4 give the results of the exploratory factor analysis. Principal axis factoring (PAF) (Schmitt, 2011) and Direct Oblimin with Kaiser Normalization (Costello \& Osborne, 2005) were chosen to perform the EFA. The ten items measuring EXL confirmed a one-factor solution with a KMO value of 0.875 , Cronbach's alpha of 0.892 and confirmed $51.2 \%$ of the variance of EXL was explained by these ten statements. The second dependent variable of ENV confirmed a one-factor solution. KMO value was 0.883 , Cronbach's alpha 0.910 confirmed the 11 statements used in the questionnaire to measure ENV and was reliable where $53.57 \%$ of variance of ENV was explained by these 11 statements. EFA confirmed the four items included in the third dependent variable of FIN as a one-factor solution with a Cronbach's alpha of 0.874 , and a KMO value of 0.788 confirming a $73.62 \%$ explanation of variance in FIN by these four items.

The EFA test examined the 22 items measuring the CHNG and suggested removing CHNG1, CHNG2, CHNG4, CHNG5, CHNG7, CHNG8, CHNG10, CHNG11, CHNG17, CHNG18, CHNG21 and CHNG22. After removing the 12 items, the Cronbach alpha was 0.885 , and $50 \%$ of the variance was explained by the remaining 10 items. The second mediating variable measuring SUSTHINK consisted of 19 statements. The EFA suggested removing SUS3, SUS6, SUS7, SUS10, SUS11, SUS17 and SUS18. KMO value of 0.876, Cronbach's alpha of 0.886 and $53.92 \%$ of the variable was explained by the remaining 12 items.

Eleven behavioural statements were identified to measure STK. The KMO value was 0.878 and Cronbach's alpha was 0.875 . It confirmed that the remaining seven statements explained $57.34 \%$ of the variance of STK construct. LONG construct had 17 behavioural statements. Low factor loading on eight items confirmed the removal of LONG3, LONG7, LONG8, LONG9, LONG10, LONG11, LONG12 and LONG13. The Cronbach's alpha of LONG is 0.873 and confirmed $50 \%$ of the variance in LONG measured by the remaining 9 items. EMP was measured by 11 leadership statements though low factor loading confirmed removing four items, namely, EMP3, EMP4, EMP5 and EMP11. Once the remaining seven items were removed it confirmed measuring 55.14\% of the variance of LONG with a Cronbach's alpha value of 0.862 and KMO value of 0.869 .

\subsection{CFA Results}

A CFA was carried out using AMOS Version 23. Appendix E shows that the descriptive model fits the statistics obtained from each CFA. ML estimation via the bootstrap method (Kline, 2005; Ullman, 2006) was used as the sample data showed a deviation from the normal distribution. All the model fit statistics were confirmed as good model fit (Appendix E). For prior testing of the hypotheses three measurement models were developed and tested for construct validity and reliability (Bagozzi, Yi, \& Phillips, 1991). Three measurement models (Appendix F) were developed to test construct validity and reliability. The first measurement model consists of three dependent variables (EXL, ENV and FIN) and confirmed as a good fit for the data (bootstrap p-value insignificant at $\mathrm{p}>0.05$, CFI, GFI, AGFI values were above 0.9, TLI $>0.95$, RMR $<0.10$ and the SRMR and RMSEA < 0.05). The second measurement model consisted of two mediating variables (CHNG and SUSTHINK). To improve the model fit CHNG6, SUS9, SUS13 and SUS15 were removed from the measurement model. The third measurement model for the three independent variables suggested removing LONG1, LONG5, LONG6, LONG14, STK9 and STK10. The final measurement model confirmed a good model fit with a Chi-square value of 60.154 (sig), insignificant P-value, CFI, GFI, AGFI and TLI values above 0.9 and the SRMR and RMSEA values less than 0.5.

Each of the three measurement models was tested individually for discriminant validity, reliability and multicollinearity (Appendix F). Discriminant validity was tested using the method suggested by Fornell and Larcker (1981). All the three measurement models confirmed its convergent validity of the constructs as suggested by Hair and Anderson (2010). All the correlations in each of the three models confirmed significant $\mathrm{p}$-values $(\mathrm{p}<0.001)$. All the three measurement models confirmed that their correlation values were less than 0.9 confirming that there was no multicolleniearity between the constructs as recommended by Tabachnick and Fidell (2001).

\subsection{Common Method Bias}

As the data used in this study was highly exposed to common method bias, some procedural remedy was applied. To eliminate the common method bias the questionnaire of this study ensured the anonymity of the respondents and their organization, and included a brief description of each construct at the beginning of each section of the questionnaire (Podsakoff, MacKenzie, Lee, \& Podsakoff, 2003). Several statistical remedies were used to understand the common method bias as recommended by Podsakoff et al. (2003). These statistical methods helped to prove that the inter-item correlation was not purely influenced by the common method variance (Korsgaard \& Roberson, 1995). First, Harman's single factor model was used to examine common method bias 
(Podsakoff et al., 2003) and was tested using three EFAs on three measurement models. The results confirmed the first model with three dependent constructs as having three factors with Eigen values greater than 1, and these three factors explained $62.5 \%$ of the variance of that model. The second measurement model with two mediating constructs confirmed two factors having Eigen values greater than 1 and with $61.9 \%$ of variance in the mediating model. The third EFA for the third measurement model confirmed three factors with Eigen Values greater than 1 while these factors accounted for $62.8 \%$ of the variance in the final independent measurement model. Harman's single factor test was conducted through the CFA method on the three separate measurement models. Sample moments option confirmed that each of the three measurement models in this study needed more than one factor to explain the constructs in the final three measurement model. The severity of methods variance was also tested using CFA on competing models that increase in complexity (McFarland \& Sweeney, 1992; Podsakoff \& Organ, 1986). The difference in Chi-square statistics was performed for the three measurement models with a simpler model. Each of the three hypothesized measurement models resulted in a better model fit of the data than the tested simpler model.

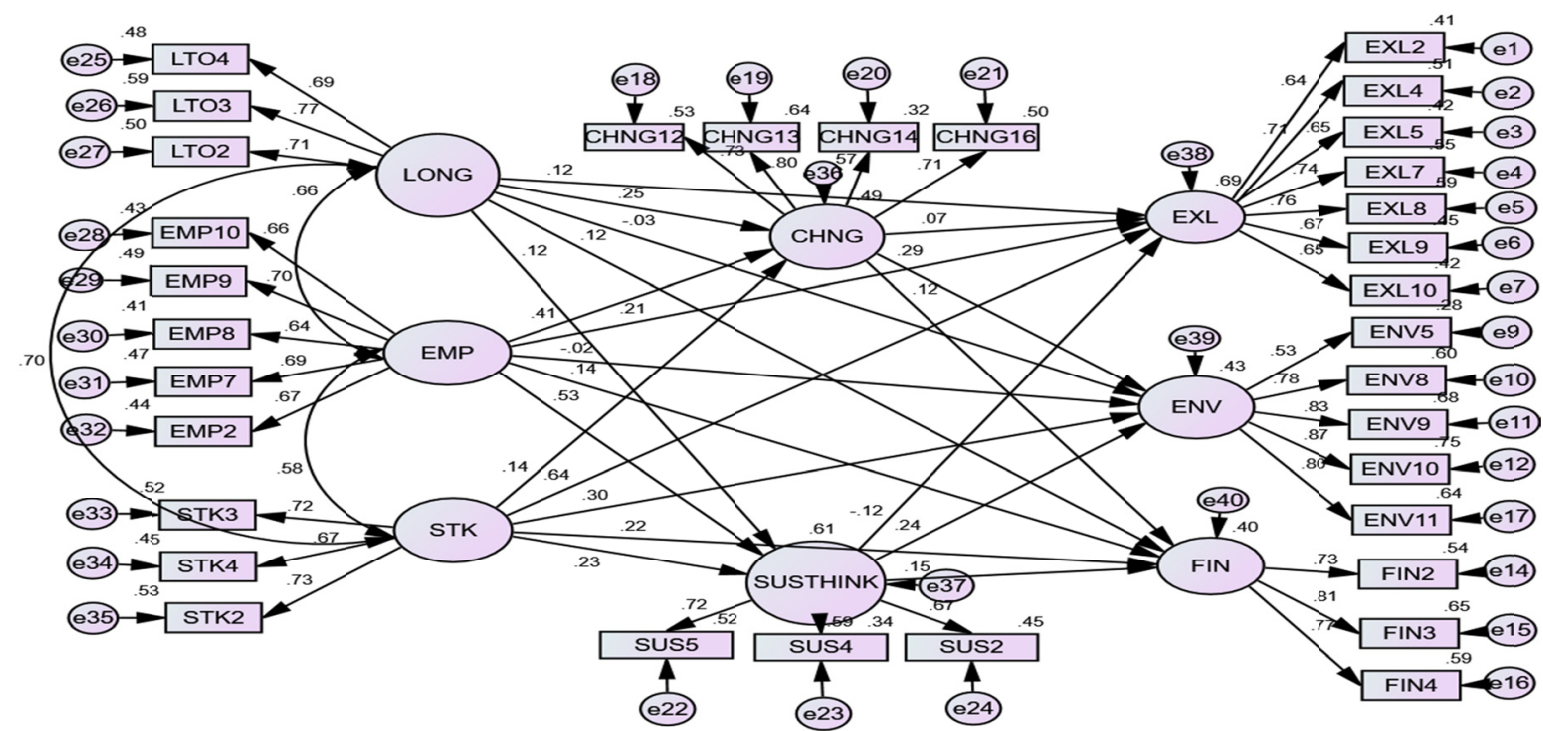

Figure 1. Developing the final SEM for sustainability leadership

Chi-square $=732.681(\mathrm{df}=469)$ significant p-values of 0.000 and bootstrap 1,000 sample $0.004, \mathrm{CMIN} / \mathrm{DF}=$ $1.562, \mathrm{CFI}=0.961, \mathrm{GFI}=0.916, \mathrm{AGFI}=0.900, \mathrm{TLI}=0.956, \mathrm{RMR}=0.026, \mathrm{RMSEA}=0.034$

The bootstrap method as well as the non-parametric method was used for SEM analysis as recommended by Ullman (2006). The initial SEM analysis confirmed a satisfactory level of model fit statistics [Chi-square = $732.681(\mathrm{df}=469), \mathrm{CMIN} / \mathrm{DF}=1.562, \mathrm{CFI}=0.961, \mathrm{GFI}=0.916, \mathrm{AGFI}=0.900, \mathrm{TLI}=0.956, \mathrm{RMR}=0.026$ and RMSEA $=0.034]$ indicating a good model fit for the sample data.

\subsection{Hypothesis Testing}

In total there were 18 hypotheses (Appendices 1 and 2) to test the relationship between the three independent variables and the three dependent variables and the two mediating variables. Research using multiple hypotheses tests needs to ensure that their statistical analysis and the results are free from Type I errors and Type II errors (Gordi \& Khamis, 2004). Hence, the Bonferroni method (Morrison, 1990) was used to control Type I errors in this study. Accordingly, each individual test was compared and confirmed at $p<0.0018$ level $(0.05 / 27=0.0018)$ not $\alpha=0.05$. Tables 1 and 2 below confirm that the standardized regression weights indicating the effect of EMP on CHNG and SUSTHINK was significant $(\mathrm{p}<0.001)$ while the effect of LONG on SUSTHINK and STK to CHNG was insignificant. The standardized regression weights from LONG to CHNG and STK to SUSTHINK were only significant at $p<0.01$. The paths from CHNG to ENV were significant only at $p<0.001$. However, the paths from CHNG to EXL and FIN were insignificant whereas the path from SUSTHINK to ENV was significant at $\mathrm{p}<0.05$ confirming a weak relationship.

The direct relationship between STK and the three dependent variables was significant whereas all the paths 
from LONG to three dependent variables were insignificant. The only direct path was from EMP to EXL but it was weak (significant at $\mathrm{P}<0.05$ ).

The mediating variables and their effects were tested separately (Tables 1 and 2 below). Due to objections to using the Baron and Kenney (1986) approach for mediation testing in complex models, the study used two other methods, namely, the bootstrapping approach of Baron and Kenney (1986) with a 99\% significance level and the Chi-square difference test statistics.

Table 1. Mediation influence of CHNG on the relationship between independent variables and the dependent variables

\begin{tabular}{|c|c|c|c|c|c|c|c|c|}
\hline \multirow[t]{2}{*}{ Hypotheses } & \multirow[t]{2}{*}{ Path } & \multirow{2}{*}{$\begin{array}{l}\text { Direct } \\
\text { without } \\
\text { mediator }\end{array}$} & \multicolumn{3}{|c|}{$\begin{array}{l}\text { Bootstrapping } 99.9 \%{ }^{\mathrm{a}} \text { and } 95 \%{ }^{\mathrm{b}} \mathrm{CI}, 1000 \\
\text { samples }\end{array}$} & \multirow{2}{*}{$\begin{array}{l}\text { Chi-square } \\
\text { difference test } \\
\Delta \chi 2(1) \\
\text { Significance } \\
99 \%\end{array}$} & \multirow{2}{*}{$\begin{array}{l}\text { Decision } \\
\text { based on } \\
\text { Mathieu and } \\
\text { Taylor } \\
(2006) \\
\end{array}$} & \multirow[t]{2}{*}{ Support } \\
\hline & & & $\begin{array}{l}\text { Direct with } \\
\text { mediator }\end{array}$ & Indirect effect & Total effect & & & \\
\hline H1 & $\begin{array}{l}\mathrm{STK} \rightarrow \\
\mathrm{EXL}\end{array}$ & $0.622 * * * a / b$ & $\begin{array}{l}0.612(\mathrm{~ns})^{\mathrm{a}} \\
0.612 * * \mathrm{~b}\end{array}$ & $0.007(\mathrm{~ns})^{\mathrm{a} / \mathrm{b}}$ & $\begin{array}{l}0.62(\mathrm{~ns})^{\mathrm{a}} \\
0.62 * * \mathrm{~b}\end{array}$ & $64.588 * * *$ & Direct & No \\
\hline $\mathrm{H} 2$ & $\begin{array}{l}\mathrm{STK} \rightarrow \\
\mathrm{ENV}\end{array}$ & $0.392 * * * a / b$ & $0.325 * * * a / b$ & $0.027(\mathrm{~ns})^{\mathrm{a} / \mathrm{b}}$ & $0.353 * * * a / b$ & $16.213 * * *$ & Direct & No \\
\hline $\mathrm{H} 3$ & $\begin{array}{l}\mathrm{STK} \rightarrow \\
\mathrm{FIN}\end{array}$ & $0.270 * * * a / b$ & $\begin{array}{l}0.226(\mathrm{~ns})^{\mathrm{a}} \\
0.226 * \mathrm{~b}\end{array}$ & $0.012(\mathrm{~ns})^{\mathrm{a} / \mathrm{b}}$ & $\begin{array}{l}0.237(\mathrm{~ns})^{\mathrm{a}} \\
0.237 * \mathrm{~b}\end{array}$ & $7.072 * *$ & Direct & No \\
\hline $\mathrm{H} 4$ & $\begin{array}{l}\mathrm{LONG} \rightarrow \\
\mathrm{EXL}\end{array}$ & $0.117(\mathrm{~ns})^{\mathrm{a} / \mathrm{b}}$ & $0.094(\mathrm{~ns})^{\mathrm{a} / \mathrm{b}}$ & $0.014(\mathrm{~ns})^{\mathrm{a} / \mathrm{b}}$ & $0.108(\mathrm{~ns})^{\mathrm{a} / \mathrm{b}}$ & $1.249(\mathrm{~ns})$ & $\begin{array}{l}\text { No } \\
\text { mediation }\end{array}$ & No \\
\hline H5 & $\begin{array}{l}\mathrm{LONG} \rightarrow \\
\mathrm{ENV}\end{array}$ & $0.072(\mathrm{~ns})^{\mathrm{a} / \mathrm{b}}$ & $-0.019(\mathrm{~ns})^{\mathrm{a} / \mathrm{b}}$ & $\begin{array}{l}0.063(\mathrm{~ns})^{\mathrm{a}} \\
0.063 * \mathrm{~b}\end{array}$ & $0.044(\mathrm{~ns})^{\mathrm{a} / \mathrm{b}}$ & $0.044(\mathrm{~ns})$ & Indirect & No \\
\hline H6 & $\begin{array}{l}\text { LONG } \rightarrow \\
\text { FIN }\end{array}$ & $0.174(\mathrm{~ns})^{\mathrm{a} / \mathrm{b}}$ & $0.123(\mathrm{~ns})^{\mathrm{a} / \mathrm{b}}$ & $0.027(\mathrm{~ns})^{\mathrm{a} / \mathrm{b}}$ & $0.150(\mathrm{~ns})^{\mathrm{a} / \mathrm{b}}$ & $1.577(\mathrm{~ns})$ & $\begin{array}{l}\text { No } \\
\text { mediation }\end{array}$ & No \\
\hline $\mathrm{H} 7$ & $\begin{array}{l}\mathrm{EMP} \rightarrow \\
\mathrm{EXL}\end{array}$ & $\begin{array}{l}0.173(\mathrm{~ns})^{\mathrm{a}} \\
0.173 * * \mathrm{~b}\end{array}$ & $0.114(\mathrm{~ns})^{\mathrm{a} / \mathrm{b}}$ & $0.02(\mathrm{~ns})^{\mathrm{a} / \mathrm{b}}$ & $0.133(\mathrm{~ns})^{\mathrm{a} / \mathrm{b}}$ & $2.912(\mathrm{~ns})$ & Direct & No \\
\hline H8 & $\begin{array}{l}\mathrm{EMP} \rightarrow \\
\mathrm{ENV}\end{array}$ & $\begin{array}{l}0.213(\mathrm{~ns})^{\mathrm{a}} \\
0.213^{* * \mathrm{~b}}\end{array}$ & $0.024(\mathrm{~ns})^{\mathrm{a} / \mathrm{b}}$ & $\begin{array}{l}0.08(\mathrm{~ns})^{\mathrm{a}} \\
0.08 * \mathrm{~b}\end{array}$ & $0.104(\mathrm{~ns})^{\mathrm{a} / \mathrm{b}}$ & $0.120(\mathrm{~ns})$ & Full & Yes \\
\hline H9 & $\begin{array}{l}\mathrm{EMP} \rightarrow \\
\mathrm{FIN}\end{array}$ & $0.260 * * * a / b$ & $0.114(\mathrm{~ns})^{\mathrm{a} / \mathrm{b}}$ & $0.04(\mathrm{~ns})^{\mathrm{a} / \mathrm{b}}$ & $0.184(\mathrm{~ns})^{\mathrm{a} / \mathrm{b}}$ & $2.70(\mathrm{~ns})$ & Direct & No \\
\hline
\end{tabular}

Note. $\mathrm{a}=99.9 \%$ significance level (according to Bonferroni method)

$$
\begin{aligned}
& \mathrm{P}<0.0018=* * * \\
& \mathrm{~ns}=\text { not significant } \\
& \mathrm{b}=95 \% \text { significance level } \\
& \mathrm{P}<0.001=* * * \\
& \mathrm{P}<0.01=* * \\
& \mathrm{P}<0.05=*
\end{aligned}
$$


Table 2. Mediation influence of manager's ethical behaviour on the relationship between independent and dependent variables

\begin{tabular}{|c|c|c|c|c|c|c|c|c|}
\hline \multirow[t]{2}{*}{ Hypotheses } & \multirow[t]{2}{*}{ Path } & \multirow{2}{*}{$\begin{array}{l}\text { Direct } \\
\text { without } \\
\text { mediator }\end{array}$} & \multicolumn{3}{|c|}{$\begin{array}{l}\text { Bootstrapping } 99.9 \%{ }^{a} \text { and } 95 \%{ }^{b} \mathrm{CI}, 1000 \\
\text { samples }\end{array}$} & \multirow{2}{*}{$\begin{array}{l}\text { Chi-square } \\
\text { difference test } \\
\Delta \chi^{2}(1) \\
\text { Significance } \\
99 \% \\
\end{array}$} & \multirow{2}{*}{$\begin{array}{l}\text { Decision } \\
\text { based on } \\
\text { Mathieu and } \\
\text { Taylor (2006) }\end{array}$} & \multirow[t]{2}{*}{ Support } \\
\hline & & & $\begin{array}{l}\text { Direct with } \\
\text { mediator }\end{array}$ & $\begin{array}{l}\text { Indirect } \\
\text { effect }\end{array}$ & Total effect & & & \\
\hline H10 & $\begin{array}{l}\mathrm{STK} \rightarrow \\
\mathrm{EXL}\end{array}$ & $0.622 * * * a / b$ & $\begin{array}{l}0.632(\mathrm{~ns})^{\mathrm{a}} \\
0.632 * * \mathrm{~b}\end{array}$ & $-0.021(\mathrm{~ns})^{\mathrm{a} / \mathrm{b}}$ & $\begin{array}{l}0.610(\mathrm{~ns})^{\mathrm{a}} \\
0.610 * * \mathrm{~b}\end{array}$ & $66.858 * * *$ & Direct & No \\
\hline H11 & $\begin{array}{l}\mathrm{STK} \rightarrow \\
\mathrm{ENV}\end{array}$ & $0.392 * * * a / b$ & $0.312 * * * a / b$ & $\begin{array}{l}0.048(\mathrm{~ns})^{\mathrm{a}} \\
0.048 * \mathrm{~b}\end{array}$ & $0.360 * * * a / b$ & $13.948 * * *$ & Partial & Yes \\
\hline H12 & $\begin{array}{l}\text { STK } \rightarrow \\
\text { FIN }\end{array}$ & $0.270 * * * a / b$ & $\begin{array}{l}0.221(\mathrm{~ns})^{\mathrm{a}} \\
0.221 * \mathrm{~b}\end{array}$ & $0.03(\mathrm{~ns})^{\mathrm{a} / \mathrm{b}}$ & $\begin{array}{l}0.250(\mathrm{~ns})^{\mathrm{a}} \\
0.250 * \mathrm{~b}\end{array}$ & $6.554 *$ & Direct & No \\
\hline H13 & $\begin{array}{l}\mathrm{LONG} \rightarrow \\
\mathrm{EXL}\end{array}$ & $0.117(\mathrm{~ns})^{\mathrm{a} / \mathrm{b}}$ & $0.088(\mathrm{~ns})^{\mathrm{a} / \mathrm{b}}$ & $-0.008(\mathrm{~ns})^{\mathrm{a} / \mathrm{b}}$ & $0.080(\mathrm{~ns})^{\mathrm{a} / \mathrm{b}}$ & $1.011(\mathrm{~ns})$ & No mediation & No \\
\hline H14 & $\begin{array}{l}\mathrm{LONG} \rightarrow \\
\mathrm{ENV}\end{array}$ & $0.072(\mathrm{~ns})^{\mathrm{a} / \mathrm{b}}$ & $-0.015(\mathrm{~ns})^{\mathrm{a} / \mathrm{b}}$ & $0.014(\mathrm{~ns})^{\mathrm{a} / \mathrm{b}}$ & $0.000(\mathrm{~ns})^{\mathrm{a} / \mathrm{b}}$ & $0.026(\mathrm{~ns})$ & No mediation & No \\
\hline H15 & $\begin{array}{l}\text { LONG } \rightarrow \\
\text { FIN }\end{array}$ & $0.174(\mathrm{~ns})^{\mathrm{a} / \mathrm{b}}$ & $0.119(\mathrm{~ns})^{\mathrm{a} / \mathrm{b}}$ & $0.009(\mathrm{~ns})^{\mathrm{a} / \mathrm{b}}$ & $0.127(\mathrm{~ns})^{\mathrm{a} / \mathrm{b}}$ & $1.445(\mathrm{~ns})$ & No mediation & No \\
\hline H16 & $\begin{array}{l}\mathrm{EMP} \rightarrow \\
\mathrm{EXL}\end{array}$ & $\begin{array}{l}0.173(\mathrm{~ns})^{\mathrm{a}} \\
0.173 * \mathrm{~b}^{\mathrm{b}}\end{array}$ & $\begin{array}{l}0.162(\mathrm{~ns})^{\mathrm{a}} \\
0.162 * \mathrm{~b}\end{array}$ & $-0.049(\mathrm{~ns})^{\mathrm{a} / \mathrm{b}}$ & $0.113(\mathrm{~ns})^{\mathrm{a} / \mathrm{b}}$ & $4.685 *$ & Direct & No \\
\hline H17 & $\begin{array}{l}\mathrm{EMP} \rightarrow \\
\mathrm{ENV}\end{array}$ & $\begin{array}{l}0.213(\mathrm{~ns})^{\mathrm{a}} \\
0.213 * 3^{*}\end{array}$ & $0.009(\mathrm{~ns})^{\mathrm{a} / \mathrm{b}}$ & $\begin{array}{l}0.094(\mathrm{~ns})^{\mathrm{a}} \\
0.094 * \mathrm{~b}\end{array}$ & $0.103(\mathrm{~ns})^{\mathrm{a} / \mathrm{b}}$ & $0.012(\mathrm{~ns})$ & Full & Yes \\
\hline $\mathrm{H} 18$ & $\begin{array}{l}\text { EMP } \rightarrow \\
\text { FIN }\end{array}$ & $0.260 * * * a / b$ & $0.133(\mathrm{~ns})^{\mathrm{a} / \mathrm{b}}$ & $0.070(\mathrm{~ns})^{\mathrm{a} / \mathrm{b}}$ & $\begin{array}{l}0.203(\mathrm{~ns})^{\mathrm{a}} \\
0.203 * \mathrm{~b}\end{array}$ & $1.827(\mathrm{~ns})$ & Direct & No \\
\hline
\end{tabular}

Note. a $=99.9 \%$ significance level (according to Bonferroni method)

$$
\begin{aligned}
& \mathrm{P}<0.0018=* * * \text { and } \mathrm{ns}=\text { not significant } \\
& \mathrm{b}=95 \% \text { significance level } \\
& \mathrm{P}<0.001=* * * \\
& \mathrm{P}<0.01=* * \\
& \mathrm{P}<0.05=* \\
& \mathrm{~ns}=\text { not significant }
\end{aligned}
$$

\section{Discussion}

\subsection{Excellence in Leadership}

The insignificant results of this study on the relationship between change leadership and excellent leadership confirmed that change activities have no positive impact on excellent leadership in Sri Lankan organisations (see Table 1 above). That is, Sri Lankan managers who participated in this study do not believe that being committed to organizational change activities will help them to become excellent leaders in their organizations. Although at the international level, change orientation is considered as essential to succeed in management (Armenakis, Harris, \& Mossholder, 1993), in the Sri Lankan context managers have negative attitudes toward change as they are fear of trade unions action (Wickramasinghe et al., 2004).

Sri Lankan managers' weak preference for long-term orientation in decision making as a means of achieving sustainability leadership is also identified in this study. It was found that managerial perceptions of long-term orientation were the least important leadership dimension in predicting Sri Lankan managerial perceptions of sustainable leadership.

The insignificant results of this study could not confirm the positive influence of traditional long-term oriented cultural and social values on Sri Lankan managerial perceptions. Therefore, this raises the question of whether in more recent times long-term orientation has become a secondary leadership skill among Sri Lankan managers. The results confirm that Sri Lankan managers believe that long-term orientation in their decision-making will positively influence their decisions that encourage organizational change. Hence, being careful and thinking of the long-term impact of change-related decisions are quite useful for sustainability in the Sri Lankan context. Especially, the long-term impact on the employees through a possible organizational change decision would protect the managers' dignity as well as limit any possible losses such as employee strikes that damage the business.

The insignificant results in this study relating to manager's ethical behaviour and excellent leadership confirm 
that the leader's ethical and responsible behaviours have no positive impact on managerial perceptions of excellent leadership in Sri Lankan organizations. Hence, Sri Lankan managers do not perceive that being trustworthy, honest, ethical and responsible in their leadership thinking is essential for excellent leadership in their organizations. This challenges the findings of Wickramasinghe et al. (2004), and Wijewardena and Wimalasiri (1996), who claimed that ethical and responsible leadership were essential for leadership success in Sri Lankan organizations.

There is no mediation effect of CHNG on the relationship between STK and EXL, where there is only a direct relationship between STK and EXL. The leadership statements show that team work, trustworthiness, and personal relationships are important for a manager to be stakeholder-orientated in the Sri Lankan organizational context. The literature relating to Sri Lankan managers emphasizes the strong desire of Sri Lankan managers to be collectivistic, team-oriented and to arrange social gatherings that develop strong relationships with its stakeholders (Hewege, 2011; Hewege et al., 2008; Ranugge, 2000; Wijewardena, 1992; Wijewardena \& Wimalasiri, 1996). Sri Lankan cultural values that prioritize strong mutual relationships, trustworthiness, honesty, compassion, obedience and care for others have probably influenced Sri Lankan managers to perceive themselves as responsible for developing a strong relationship with stakeholders in order to become sustainable leaders. Also, Sri Lankan managers give more priority to solving crucial employee matters, showing empathy towards employees, and being ready to sacrifice their time as they believe this enables them to transform their organization and to excel in organizational leadership. This suggests that Sri Lankan managers should demonstrate affection, caring and other paternalistic behaviours towards stakeholders including employees to achieve excellent management success in the Sri Lankan organizational context.

\subsection{Sri Lankan Manager's Concern for Social and Environmental Sustainability}

The difference in the Chi-square test to examine the mediation of CHNG on STK and ENV confirmed that there was no mediation effect of CHNG on the relationship between STK and ENV, but only a direct relationship between the variables. This confirmed that Sri Lankan manager's strong team work and public relationship management directly enabled them to ensure environmental and social sustainability. Sri Lankan Buddhist values and the rituals and respect towards the Bodhi tree also influence Sri Lankan attitudes to collectively protect the environment (Kariyawasam, 1996). This finding is in line with that of Avery and Bergsteiner (2011); Caldwell (2003); Hargett and Williams (2009); Parkin (2010) and Salem (2012) whose research suggested that managers' positive attitudes towards stakeholder relationships improve social and environmental sustainability. The findings are in line with Fernando and Almeida (2012) suggestions that Sri Lankan managers believe that they can ensure sustainability through encouraging collaboration, networking, public relationships and team work with diverse stakeholders.

This finding contradicts the findings of Crawford and Nahmias (2010), who suggested that stakeholder relationships are essential to change organizations. High influential power and authority (Chandrakumara \& Sparrow, 2004), social mistrust especially due to ethnic conflicts (Somasundaram \& Sivayokan, 2013), high power distance between social classes, influence of imperialism (Wijewardena \& Wimalasiri, 1996) have impacted on Sri Lankan leaders to perceive that stakeholder relationships are not important for changing their organization.

Partial mediation indicates that Sri Lankan managers' stakeholder orientation enhances their decisions for ethical behaviour, which, in turn, enables them to achieve environmental and social sustainability. Although the literature suggests having strong stakeholder relationships helps mangers to achieve successful organizational transformation, the findings of this study indicate that Sri Lankan managers' perceptions of stakeholder orientation do not support this concept. Cultural values such as resistance to change and strong employee union power seem to have influenced Sri Lankan managers to perceive stakeholder relationships as insignificant for successful change implementation. However, managers' ignorance of the participation of stakeholders in change implementation is also identified in the literature as the main reasons for common disputes between Sri Lankan managers and labour unions (Wickramasinghe et al., 2004).

This study's insignificant results regarding the direct relationship between long-term orientation and social and environmental sustainability confirm that Sri Lankan managers perceive long-term orientation as having no significant effect on protecting the social and natural environment. This suggests instances where Sri Lankan employees prefer quick solutions from their managers for their grievances (Wickramasinghe et al., 2004); thus, spending too much time or deep analysis of the problem would probably be perceived as threatening social and environmental harmony. These experiences might influence managers to perceive being long-term oriented in decision making as a disadvantage in protecting society and environment. 
This study's insignificant results regarding the direct relationship between employee orientation and social and environmental sustainability confirm that Sri Lankan managers do not believe that being employee-oriented will positively impact on their perceptions of social and environmental sustainability. That is, Sri Lankan managers do not believe transformational leadership behaviours such as delegation, sharing authority and autonomy, and encouraging leader-member communication and employee decision-making have a direct influence on social and environmental sustainability.

The findings confirm that Sri Lankan managers perceive organizational-change-related activities as essential for achieving social and environmental sustainability. For example, the Sri Lankan garment industry has changed its traditional practices to face international competition through introducing more socially and environmentally responsible production methods (Perry, 2013).

The significant results confirm that Sri Lankan managerial perceptions relating to manager's ethical behaviour positively influence their perceptions of social and environmental sustainability. Sri Lankan cultural values have influenced Sri Lankan managers to believe their attitudes towards social harmony, safety, caring and self-discipline, which, in turn, help to protect their immediate environment and social sustainability. Even, leaders with of exemplary character that conduct ethical practices even in their personal lives were respected by employees (Wijewardena \& Wimalasiri, 1996) so managers fear breaching ethical standards may harm their personal image and could prevent them from achieving paternalistic leadership relations with their subordinates (Wickramasinghe \& Hopper, 2005). Such cultural values have no doubt influenced Sri Lankan managers to perceive their ethical behaviour as an important leadership dimension for enabling social and environmental harmony. The young generations of Sri Lanka consider traditional values of ethnocentrism, power distance between different levels in the hierarchy, and the male-dominant cultural values as barriers to social harmony (UNDP, 2019). It seems values are promoting organizational leaders to think more ethically to achieve social and environmental protection (United Nations Educational Scientific and Cultural Organization, 2018).

This study's bootstrap mediation results confirm that employee engagement and social and environmental sustainability are fully mediated through the two mediators of change leadership and ethical behaviour. Cultural diversity, ethnic conflict, dependence on export and import markets, risks associated with natural disasters, and financial and economic dependence on developed countries may have previously influenced Sri Lankan managers to believe that employee engagement is not enough to ensure environmental, social and economic sustainability. The cultural, political and economic transformation of Sri Lanka has instead influenced its managers to believe they can enhance environmental, social and economic sustainability by changing their organizations, as well as through encouraging manager's ethical behaviour.

In conclusion, these results have confirmed that Sri Lankan managers perceive that they can achieve environmental and social sustainability via engagement with stakeholders and employees, but not by being long-term-oriented.

\subsection{Firms' Concern for Financial Sustainability}

Achieving financial targets and focusing on maximizing productivity are the two measures of this construct, the second item being the most important leadership behaviour in this construct. This study's significant results regarding the relationship between stakeholder relationships and the firm's financial performance confirm that Sri Lankan managers believe that stakeholder relationships improve their firm's future prosperity. This might be due to a weak national economy, rising costs of manufacturing, an exports-driven economy that demands cheap manufacturing costs, the impact of international financial crises, and shrinking of the world's consumption (Central Bank of Sri Lanka, 2018) seem to have influenced Sri Lankan managers to be concerned about collaborating with diverse parties as a means of strengthening firms' financial performances. Sri Lankan managers believe that increasing stakeholder value rather than shareholder value would enhance financial performance of the organization (Fernando \& Almeida, 2012).

Bootstrap mediation test results confirmed that the two mediators have no significant influence on the relationship between the stakeholder relationships and the firm's financial performance. The insignificant results confirm that Sri Lankan managers do not believe they can achieve greater organizational financial performance outcomes by promoting manager's ethical behaviour in their decisions. This might be a reason why Sri Lankan managers perceive that being ethical and responsible will build their personal image as most respected managers rather than increasing the financial performance of their organization. The insignificant result of this study regarding the relationship between change leadership and financial performance, contradicts the suggestion made by Ferguson and Reio (2010) that management's change efforts should positively influence the firm's performance. Cultural values that resist change and the cost associated with it might have influenced Sri Lankan 
managers to perceive that a possible organizational change would mean greater cost than income for the organization.

\section{Conclusion}

This study aimed to examine the mediation effect of managers' change-related attitudes and ethical behaviour on creating sustainability leadership in Sri Lankan organizations. Three leadership dimensions (EMP, LONG and STK) were identified as influencing managerial perceptions of sustainability leadership in Sri Lanka.

The results of this study results suggest that long-term orientation is the least important leadership dimension in achieving sustainability leadership in Sri Lankan organizations while stakeholder relationship is the most important leadership dimension.

The literature emphasizes the importance of organizational change as novel and important leadership dimensions that ensure sustainability leadership. However, the standardized regression weights and the results of the mediation analysis of this study show that the perceptions of the manager's commitment to organizational change only influence establishing environment and social sustainability, and do not influence either the perceptions of excellent leadership or concern for financial performance. Hence, the results show that change leadership attitudes are essential for establishing social and environmental sustainability in the Sri Lankan context. Resistance to change that is common among many Sri Lankan managers suggests that they can enhance their change attitudes via formal management training programs. Therefore, HR units and departments of Sri Lankan organizations should design management training programs to enhance these change managerial skills.

The mediation test results confirm that the relationship between the manager's perception of employee engagement and concern for social and environmental sustainability is fully mediated by the managers commitment to organizational change and their ethical behaviour. That is, Sri Lankan managers believe they can only enhance social and environmental sustainability by encouraging organizational change and by promoting manager's ethical behaviour in their decision making.

\subsection{Recommendations}

\subsubsection{For Managers}

Improving leadership skills such as team management skills and public relations management skills is important for sustainability leadership in Sri Lanka. Managers should also identify and categorize diverse stakeholders such as employees, customers, trade unions, industry associations and supply chain partners based on their potential importance for the organization and managing these stakeholders to enhance sustainability in Sri Lankan organizations.

Since the results confirm the power of stakeholder relationship and employee engagement Sri Lankan organizations should prioritize customer satisfaction and seek more ways of gathering employee feedback to enhance organizational sustainability. Surveys and face-to-face communications could also be used to identify employee satisfaction, especially with their immediate managers. Expatriates and foreign managers of MNCs understanding the 'soft side' of Sri Lankan cultural values would help to achieve sustainability leadership in the Sri Lankan organizational context.

It will also be useful for HR managers, management trainers and consultants to acknowledge and support sustainability as a main learning objective of management training and employee development programs at all levels in the organizational hierarchy. These programs should aim to develop sustainability management skills especially in developing trust and confidence among their subordinates and to be more employee-oriented in their decision-making towards creating sustainable leadership. Managers can organize local and international management forums to share stories of excellent sustainable organizations which would probably benefit managers.

\subsubsection{For Policy Makers}

This study highlights the importance of management training and development programs conducted by educational institutes through workshops, seminars and conferences involving the corporate sector for sharing practical ways of achieving social, environmental and economic sustainability.

Proactive coordination between the private and public sector should be encouraged to fulfill real community needs rather than corporations trying to invest in ad hoc CSR projects that do not solve the true problems of society.

Policymakers should encourage local authorities such as the environmental and accounting authorities (e.g., Sri Lanka Accounting Standards, International Accounting Standards) and quality standard bodies such as the 
International Organization for Standards to update their standards and disclosure requirements at the international level. These new changes should be effectively communicated and implemented by the corporate sector to ensure the sustainability of Sri Lankan organizations.

\subsection{Future Research}

This study was limited to the Sri Lankan organizational context and hence future researchers could extend this to other countries to develop a sustainability leadership model that is useful for describing more diverse managerial perceptions of sustainability. Future researchers could conduct invariance testing and cross-cultural comparative studies to analyze managerial perceptions of sustainability leadership characterized as multicultural and multi-ethnic.

This study confirms the importance of managers' ethical behaviour to achieve sustainable leadership. Future scholars could explore the influence of Buddhist philosophy in shaping managerial behaviours via invariance testing that concentrates on a larger sample of Buddhist managers especially focusing on the tradition of spiritualism, which has been largely ignored by management scholars.

Further, they could identify how manager's ethical behaviour emerges within oneself, and how these moral attitudes gradually extend to one's immediate family, and then to society in the Sri Lankan cultural context. Hence, future researchers could investigate diverse philosophical and cultural factors that influence management perceptions relating to manager's ethical behaviour that would enhance the social, environmental and financial sustainability of the firm.

It was identified here that Sri Lankan managers' negative attitudes to change hinder their achievement of excellence in leadership. Thus, future researchers could explore how change-oriented leadership skills can improve the leadership attitudes of Sri Lankan managers, too. Future researchers could also examine the aggregate influence of national cultural values on managerial perceptions via a much larger representative sample using a longitudinal design such as the multi-wave method. Managers' preference for short-term oriented decision making could be further explored with a much larger and representative managerial sample using either quantitative or qualitative methodology. The methodology, questionnaire and the research approach used in this study could be used to explore sustainability leadership in other regions, countries and industries. Comparative studies could also be conducted using larger samples across multiple industries, countries and regions.

\section{Acknowledgement}

The author wishes to thank Prof. Christopher Selvarajah and Dr. Aron Perenyi from Swinburne University of Technology, Melbourne, Australia for the enormous support, guidance and encouragement given to complete this project.

\section{References}

Abeysekera, R. (2007). The impact of human resource management practices on marketing executive turnover of leasing companies in Sri Lanka. Contemporary Management Research, 3(3), 233-252. https://doi.org/10.7903/cmr.94

Akins, R., Bright, B., Brunson, T., \& Wortham, W. (2013). Effective Leadership for Sustainable Development. E-Journal of Organizational Learning and Leadership, 11(1).

Armenakis, A. A., Harris, S. G., \& Mossholder, K. W. (1993). Creating readiness for organizational change. Human Relations, 46(6), 681-703. https://doi.org/10.1177/001872679304600601

Avery, G. C., \& Bergsteiner, H. (2010). Honeybees and Locusts: The business case for sustainable leadership. Firstedn, Allen \& Unwin, NSW, Australia.

Avery, G. C., \& Bergsteiner, H. (2011). Sustainable Leadership: Honeybee and Locust Approaches. New York: Routledge.

Bagozzi, R. R., Yi, Y., \& Phillips, L. W. (1991). Assessing construct validity in organizational research. Administrative Science Quarterly, 56, 421-458. https://doi.org/10.2307/2393203

Baron, R. M., \& Kenny, D. A. (1986). The moderator-mediator variable distinction in social psychological research: Conceptual, strategic, and statistical considerations. Journal of Personality and Social Psychology, 51(6), 1173-1182. https://doi.org/10.1037/0022-3514.51.6.1173

Bass, B. M. (1990). Bass and Stodgill's handbook of leadership (3rd ed.). New York: Free Press.

Bass, B. M., \& Avolio, B. J. (1993). Transformational leadership: A response to critiques. San Diego: Academic Press. 
Bin, L. (2020). China's Road and Its Illuminations toward Developing Countries. In On China's Road (pp. 215-233). Singapore: Palgrave Macmillan. https://doi.org/10.1007/978-981-13-7880-5_9

Bossink, B. A. G. (2007). Leadership for sustainable innovation. International Journal of Technology Management \& Sustainable Development, 6, 135-149. https://doi.org/10.1386/ijtm.6.2.135_1

Caldwell, R. (2003). Change leaders and change managers: different or complementary? Leadership \& Organization Development Journal, 24(5), 285-293. https://doi.org/10.1108/01437730310485806

Central Bank of Sri Lanka. (2018). Annual Report. Central Bank, Colombo, Sri Lanka.

Chandrakumara, A., \& Sparrow, P. R. (2004). Exploring Meaning and Values of Work Orientation as an Element of National Culture and Its Impact on HRM Policy-Practice Design Choices: Lessons From Sri Lankan Domestic and Foreign-Invested Firms. International Journal of Manpower, 25(6), 564-589. https://doi.org/10.1108/01437720410560451

Costello, A. B., \& Osborne, J. (2005). Best practices in exploratory factor analysis: Four recommendations for getting the most from your analysis. Practical Assessment, Research, and Evaluation, 10(1), 7.

Crawford, L., \& Nahmias, A. H. (2010). Competencies for managing change. International Journal of Project Management, 28(4), 405-412. https://doi.org/10.1016/j.ijproman.2010.01.015

D'Amato, A., \& Roome, N. (2009). Toward an integrated model of leadership for corporate responsibility and sustainable development: A process model of corporate responsibility beyond management innovation, Corporate Governance, 9(4), 421-434. https://doi.org/10.1108/14720700910984972

Donaldson, T., \& Preston, L. (1995). The stakeholder theory of the corporation: Concepts, evidence and implications. Academy of Management Review, 20(1), 65-91. https://doi.org/10.5465/amr.1995.9503271992

Doppelt, B. (2012). The power of sustainable thinking: How to create a positive future for the climate, the planet, your organization and your life. England: Routledge. https://doi.org/10.4324/9781849773232

Dunphy, D., \& Benn, S. (2013). Organisational change, leadership and ethics: Leading organisations towards sustainability. In R. Todnem \& B, Burnard (Eds.), Leadership for sustainable futures (pp. 195-215). London: Routledge.

Dunphy, D., Griffiths, A., \& Benn, S. (2014). Organisational change for corporate sustainabilit (3rd ed.). London: Routledge.

Edirisinghe, H. (2008). Strategic management practices of Sri Lankan commercial banks. PhD thesis, Australian Graduate School of Entrepreneurship, Swinburne University of Technology Melbourne, Australia.

Edjossan-Sossou, A. M., Galvez, D., Deck, O., Al Heib, M., Verdel, T., Dupont, L., \& Morel, L. (2020). Sustainable risk management strategy selection using a fuzzy multi-criteria decision approach. International Journal of Disaster Risk Reduction, 101474. https://doi.org/10.1016/j.ijdrr.2020.101474

Fahr, J. L., Podsakoff, P. M., \& Cbeng, B. S. (1987). Culture-free leadership effectiveness versus moderators of leadership behaviors: An extension and test of Kerr and Jermier's 'substitutes for leadership' model in Taiwan. Journal of International Business Studies, 18, 43-60. https://doi.org/10.1057/palgrave.jibs. 8490411

Ferguson, K. L., \& Reio, T. G. J. (2010). Human resource management systems and firm performance. Journal of Management Development, 29(5), 471-494. https://doi.org/10.1108/02621711011039231

Fernando, M., \& Almeida, S. (2012). The organizational virtuousness of strategic corporate social responsibility: A case study of the Sri Lankan family-owned enterprise MAS Holdings. European Management Journal, 30(6), 564-576. https://doi.org/10.1016/j.emj.2012.08.003

Fornell, C., \& Larcker, D. F. (1981). Evaluating structural equation models with unobservable variables and measurement error. Journal of Marketing Research, 18(February), 39-50. https://doi.org/10.1177/002224378101800104

Geekiyanage, N., \& Vithanage, M. (2015). State of the environment, environmental challenges and governance in Sri Lanka. In Environmental Challenges and Governance (pp. 116-132). Routledge.

Ghassim, B., \& Foss, L. (2020). How Do Leaders Embrace Stakeholder Engagement for Sustainability-Oriented Innovation? In New Leadership in Strategy and Communication (pp. 63-80). Springer, Cham. https://doi.org/10.1007/978-3-030-19681-3_6 
Gilbert, B. (2019). Cultivating a Community of Resilience for Transgender Collegians through the Practice of Sustainable Leadership.

Global Reporting Initiative. (2016). GRI 201 Economic Performance. Global Reporting Initiative, Amesterdam, The Netherlands.

Gordi, T., \& Khamis, H. (2004). Simple solution to a common statistical problem: Interpreting multiple tests. Clinical Therapeutics, 26(5), 780-786. https://doi.org/10.1016/S0149-2918(04)90078-1

Gunarathne, N., de Alwis, A., \& Alahakoon, Y. (2020). Challenges facing sustainable urban mining in the e-waste recycling industry in Sri Lanka. Journal of Cleaner Production, 251, 119641. https://doi.org/10.1016/j.jclepro.2019.119641

Hair, J. F., \& Anderson, R. E. (2010). Multivariate data analysis (7th ed.). Prentice Hall Higher Education, New Jersey.

Hamlin, R. G., \& Patel, T. (2020). Toward an emergent Asian behavioural model of perceived managerial and leadership effectiveness: A cross-nation comparative analysis of effective and ineffective managerial behaviour of private sector managers in India and South Korea. Human Resource Development International, 1-24. https://doi.org/10.1080/13678868.2019.1700076

Hargett, T. R., \& Williams, M. F. (2009). Wilh. Wilhelmsen Shipping Company: Moving from CSR tradition to CSR leadership. Corporate Governance, 9(1), 73-82. https://doi.org/10.1108/14720700910936074

Hewage, C. R. (2011). Acculturation and Management Control-Japanese Soul in Sri Lankan Physique. Contemporary Management Research, 7(1), 3-20. https://doi.org/10.7903/cmr.6256

Hewage, C. R., Teicher, J., Alam, Q., \& VanGramberg, B. (2008). Postmortem of Post-Liberalisation SOE Governance in Sri Lanka: The Duality of Rational-Legal and Feudal-Patrimonial. Faculty of Business, Queensland University of Technology, Brisbane, Qld.

Hewamanne, S. (2020). Emergency Contraceptives are our Saviours: Sri Lanka's Global Factory workers Negotiating Reproductive Health. Journal of International Women's Studies, 22(1). Retrieved from http://repository.essex.ac.uk/id/eprint/26628

Hinkin, T. R. (1998). A brief tutorial on the development of measures for use in survey questionnaires. Organizational Research Methods, 1(1), 104-121. https://doi.org/10.1177/109442819800100106

Hofstede, G. (1986). Culture's consequences: International differences in work-related values. London: SAGE.

Hofstede, G., \& Bond, M. H. (1988). The Confucian connection: From cultural roots to economic growth. Organizational Dynamics, 16(Spring), 5-21. https://doi.org/10.1016/0090-2616(88)90009-5

House, R. J., \& Aditya, R. N. (1997). The social scientific study of leadership: Quo Vadis? Journal of Management, 23, 409-473. https://doi.org/10.1016/S0149-2063(97)90037-4

House, R. J., Hanges, P. J., Ruiz-Quintanilla, S. A., Dorfman, P. W., Javidan, M., Dickson, M., \& Gupta, V. (1999). Cultural influences on leadership and organizations: Project GLOBE. Stamford, CT: JAI Press.

House, R. J., \& Javidan, M. (2004). Overview of GLOBE. Thousand Oaks, CA: SAGE.

Javidan, M., \& House, R. J. (2001). Cultural acumen for the global manager: Lessons from Project GLOBE. Organizational Dynamics, 29(4), 289-305. https://doi.org/10.1016/S0090-2616(01)00034-1

Jayawardana, A. K. L., O’Donnell, M., \& Jayakody, J. A. S. K. (2013). Job involvement and performance among middle managers in Sri Lanka. The International Journal of Human Resource Management, 24(21), 4008-4025. https://doi.org/10.1080/09585192.2013.781526

Joreskog, K. G. (1993). Testing structural equation models. SAGE, Newbury Park.

Kalshoven, K., Den Hartog, D. N., \& De Hoogh, A. H. (2011). Ethical leadership at work questionnaire (ELW): Development and validation of a multidimensional measure. The Leadership Quarterly, 22(1), 51-69. https://doi.org/10.1016/j.leaqua.2010.12.007

Kamalika, P. (2008). Home and family in ancient and medieval Sri Lanka. The Island online: Saturday Magazine, 6, 1 .

Kantabutra, S., \& Avery, G. (2012). Sustainable leadership at Siam Cement Group. Journal of Business Strategy, 32(4), 32-41. https://doi.org/10.1108/02756661111150954

Kantabutra, S., \& Saratun, M. (2013). Sustainable leadership: Honeybee practices at Thailand's oldest university. 
International Journal of Educational Management, 27(4), 356-376. https://doi.org/10.1108/09513541311316304

Karande, K., Rao, C. P., \& Singhapakdi, A. (2002). Moral Philosophies of Marketing Managers: A Comparison of American, Australian, and Malaysian Cultures. European Journal of Marketing, 36(7/8), 768-791. https://doi.org/10.1108/03090560210430791

Kariyawasam, A. G. S. (1996). Buddhist Ceremonies and Rituals of Sri Lanka. Retrieved December 2, 2013, from http://www.accesstoinsight.org/lib/authors/kariyawasam/wheel402.html

Khavul, S., \& Bruton, G. D. (2013). Harnessing Innovation for Change: Sustainability and Poverty in Developing Countries. Journal of Management Studies, 50(2), 285-306. https://doi.org/10.1111/j.1467-6486.2012.01067.x

Kline, R. B. (2005). Principles and practice of structural equation modeling (2nd ed.). New York: Guilford Press.

Korsgaard, M. A., \& Roberson, L. (1995). Procedural Justice in Performance Evaiuation: The Role of instrumental and Non-Instrumental Voice in Performance Appraisal Discussions. Journal of Mangement, 21(4), 657-669. https://doi.org/10.1177/014920639502100404

Laurent, A. (1986). The cross cultural puzzle of international human resource management. Human Resource Management, 25(1), 91-102. https://doi.org/10.1002/hrm.3930250107

Liyanage, U. (1996a). Femininity as a managerial value. Sri Lankan Journal of Management, 1(1), (January-March), 37-47.

Liyanage, U. (1996b). Profiling the Emerging Sri Lankan Culture. Sri Lankan Journal of Management, 2(1), 3552.

Löfsten, H., Klofsten, M., \& Cadorin, E. (2020). Science Parks and talent attraction management: university students as a strategic resource for innovation and entrepreneurship. European Planning Studies, 1-24. https://doi.org/10.1080/09654313.2020.1722986

McFarland, D. B., \& Sweeney, P. D. (1992). Distributive and procedural justice as predictors of satisfaction with personal and organizational outcomes. Academy of Management Journal, 35(3), 626-637. https://doi.org/10.5465/256489

Metclaf, L., \& Benn, S. (2013). Leadership for sustainability: An evolution of leadership ability. Journal of Business Ethics, 112, 369-384. https://doi.org/10.1007/s10551-012-1278-6

Millar, C., Hind, P., \& Magala, S. (2012). Sustainability and the need for change: organisational change and transformational vision. Journal of Organizational Change Management, 25(4), 489-500. https://doi.org/10.1108/09534811211239272

Ministry of Environment. (2012). Country Report of Sri Lanka-UN conference on Sustainable Development: Sri Lanka's Middle Path to Sustainable Development through 'Mahinda Chintana - Vision for the Future'. Ministry of Environment, Battaramulla, Sri Lanka.

Morrison, D. F. (1990). Multivariate Statistical Methods. New York: McGraw-Hill.

Murdoch, G. (1967). Ethnographic atlas. Pittsburgh, PA: University of Pittsburgh Press.

Murphy, M. (2002). Organisational Change and Firm Performance. Paris: OECD Publishing.

Nanayakkara, G. (1999). Culture and Management in Sri Lanka. Colombo - Sri Lanka.

Ovadje, F. (2014). Change Leadership in Developing Countries. Routledge. https://doi.org/10.4324/9780203576458

Parkin, S. (2010). The Positive Deviant Sustainability Leadership in a Perverse World. Earthscan, London. https://doi.org/10.4324/9781849776578

Parson, T. (1951). The Social System. New York: Free Press.

Perry, P. (2013). Garments without guilt?: A case study of sustainable garment sourcing in Sri Lanka. $\begin{array}{lllll}\text { Sustainability in } \text { Fashion } & \text { 294-307. }\end{array}$ https://doi.org/10.9774/GLEAF.978-1-909493-61-2_20

Peterson, M. F., \& Hunt, J. G. (1997), International perspectives on international leadership. The Leadership Quarterly, 8(3), 203-231. https://doi.org/10.1016/S1048-9843(97)90002-3 
Podsakoff, P. M., MacKenzie, S. B., Lee, J. Y., \& Podsakoff, N. P. (2003). Common method biases in behavioural research: A critical review of the literature and recommended remedies. Journal of Applied Psychology, 88(5), 879-903. https://doi.org/10.1037/0021-9010.88.5.879

Podsakoff, P. M., \& Organ, D. W. (1986). Self-reports in organizational research: Problems and prospects. Journal of Management, 12, 531-544. https://doi.org/10.1177/014920638601200408

Polansky, M. J. (1995). Incorporating the natural environment in corporate strategy: A stakeholder approach. The Journal of Business Strategies, 12(2),151-168.

Porter, M. E., \& Kramer, M. R. (2006). Strategy and society: The link between competitive advantage and corporate social responsibility. Harvard Business Review, 84(12), 78-92.

Post, J., Preston, L., \& Sachs, S. (2002). Managing the extended enterprise: The new stakeholder view. California Management Review, 45, 6-28. https://doi.org/10.2307/41166151

Ranugge, S. (2000). State, bureaucracy and development. Delhi: Macmillian.

Salem, A. A. H. (2012). Leading to heal: A view of sustainability leadership. In D. R. Gallagher (Ed.), Environmental leadership a reference handbook. Thousand Oaks, California: SAGE Publications. https://doi.org/10.4135/9781452218601.n5

Scanduraa, T., \& Dorfman, P. (2004). Leadership research in an international and cross-cultural context. The Leadership Quarterly, 15, 277-307. https://doi.org/10.1016/j.leaqua.2004.02.004

Schmitt, T. A. (2011). Current Methodological Considerations in Exploratory and Confirmatory Factor Analysis. Journal of Psycholoeducational Assessment, 29, 304-321. https://doi.org/10.1177/0734282911406653

Selvarajah, C. (2008). Cultural diversity management in Malaysia: A study of Indian, Chinese and Malay business leadership. New Delhi: Taj McGraw Hill.

Selvarajah, C., Duignan, P., Suppiah, C., Lane, T., \& Nuttman, C. (1995). In Search of the ASEAN Leader: An Exploratory Study of the Dimensions That Relate to Excellence in Leadership. Management International Review, 35(1), 29-44.

Selvarajah, C., \& Meyer, D. (2006). Archetypes of the Malaysian manager: Exploring dimensions that relate to leadership. Journal of Management and Organisation, 12(3), 251-269. https://doi.org/10.1017/S1833367200003990

Selvarajah, C., Meyer, D., \& Davuth, D. (2012). The effect of cultural modelling on leadership profiling of the Cambodian manager. Asia Pacific Business Review, 18(4), 649-674. https://doi.org/10.1080/13602381.2012.690256

Selvarajah, C., Meyer, D., \& Donovan, J. (2013). Cultural context and its influence on managerial leadership in Thailand. Asia Pacific Business Review, 19(3), 356-380. https://doi.org/10.1080/13602381.2012.714630

Selvarajah, C., Meyer, D., Jayakody, J. A. S. K., \& Sukunesan, S. (2020). Managerial Perceptions of Leadership in Sri Lanka: Good Management and Leadership Excellence as Foundation for Sustainable Leadership Capacity Building in Post-Civil War Sri Lanka. Sustainability, 12(4), 1307. https://doi.org/10.3390/su12041307

Sohal, A. S., Gordon, J., Fuller, G., \& Simon, A. (1999). Manufacturing Practices and Competitive Capability: An Australian Study. Technovation, 19(5), 295-304. https://doi.org/10.1016/S0166-4972(98)00121-7

Somasundaram, D., \& Sivayokan, S. (2013). Rebuilding community resilience in a post-war context: Developing insight and recommendations-a qualitative study in Northern Sri Lanka. International Journal of Mental Health Systems, 7(1), 1-25. https://doi.org/10.1186/1752-4458-7-3

Strategic Direction. (2011). Becoming more sustainable: The role of leadership and innovation. Emerald Group Publishing Limited, 27(7), 24-27. https://doi.org/10.1108/02580541111137056

Tabachnick, B. G., \& Fidell, L. S. (2001). Using multivariate statistics (4th ed.). Allyn and Bacon, Boston, Mass.

Triandis, H. C. (1995). Individualism and Collectivism. Boulder, CO, US: Westview Press.

United Nations. (2015). Genral Assembly-Transforming our world: The 2030 Agenda for Sustainable Development United Nations. New York, United States.

United Nations Development Programme. (2019). Sri Lankan National Human Development Report. United 
Nations Developement Programme (UNDP), Sri Lanka.

United Nations Educational Scientific and Cultural Organization. (2018). Biodiversity and sustainability education in Sri Lanka. Retrieved February 7, 2018, from https://en.unesco.org/aspnet/globalcitizens/act/twinnings/biodiversity-sustainability-education-sri-lanka

Ullman, J. B. (2006). Structural equation modeling: Reviewing the basics and moving forward. Journal of Personality Assessment, 87, 35-50. https://doi.org/10.1207/s15327752jpa8701_03

Wakabayashi, M., \& Green, G. (1984). The Japanese career progress study: A seven year follow-up. Journal of Applied Psychology, 69, 603-614. https://doi.org/10.1037/0021-9010.69.4.603

Wickramasinghe, D., Hopper, T., \& Rathnasiri, C. (2004). Japanese cost management meets Sri Lankan politics: Disappearance and reappearance of bureaucratic management controls in a privatised utility. Accounting Auditing \& Accountability Journal, 17(1), 85-120. https://doi.org/10.1108/09513570410525229

Wijewardena, H. (1992). Management practices in the United States and Japan, and their relevance to Sri Lanka. Vidyodaya Journal of Social Science, 6(1-2), 1-18.

Wijewardena, H., \& Wimalasiri, J. S. (1996). In search of an Asian Style of Management. Sri Lankan Journal of Management, 1(2), (April-June).

Willard, B. (2009). The sustainability champion's guidebook how to transform your company. Gabriola Island, B.C.: New Society Publishers.

Wondirad, A., Toolache, D., \& King, B. (2020). Stakeholder collaboration as a major factor for sustainable ecotourism development in developing countries. Tourism Management, 78, 104024. https://doi.org/10.1016/j.tourman.2019.104024

Yukl, G. A. (2012). Effective Leadership Behaviour: What we know and what questions need more attention. Academy of Management Perspectives, 26(4), 66-85. https://doi.org/10.5465/amp.2012.0088

\section{Appendix A}

Hypotheses development to test manager's ethical behaviour mediates the relationship between leadership excellence and sustainability leadership dimensions

\footnotetext{
H1: The leader's ethical behaviour mediates the relationship between concern for stakeholder relationship and excellent leadership in the Sri Lankan organisational context.

H2: The leader's ethical behaviour mediates the relationship between concern for stakeholder relationship and concern for social and environmental sustainability in the Sri Lankan organisational context.

H3: The leader's ethical behaviour mediates the relationship between concern for stakeholder relationship and concern for financial performance in the Sri Lankan organisational context.

H4: The leader's ethical behaviour mediates the relationship between long-term decision making and excellent leadership in the Sri Lankan organisational context.

H5: The leader's ethical behaviour mediates the relationship between long-term decision making and concern for social and environmental sustainability in the Sri Lankan organisational context.

H6: The leader's ethical behaviour mediates the relationship between long-term decision making and concern for financial performance in the Sri Lankan organisational context.

H7: The leader's ethical behaviour mediates the relationship between employee engagement and excellent leadership in the Sri Lankan organisational context.

H8: The leader's ethical behaviour mediates the relationship between employee engagement and concern for social and environmental sustainability in the Sri Lankan organisational context H9: The leader's ethical behaviour mediates the relationship between employee engagement and concern for financial performance in the Sri Lankan organisational context.
} 


\section{Appendix B}

Hypotheses development to test the organisational change mediates the relationship between leadership excellence and sustainability leadership dimensions

H10: The leader's commitment to organisational change (CHNG) mediates the relationship between concern for stakeholder relationship (STK) and excellent leadership (EXL) in the Sri Lankan organisational context.

H11: The leader's commitment to organisational change (CHNG) mediates the relationship between concern for stakeholder relationship (STK) and concern for social and environmental sustainability (ENV) in the Sri Lankan organisational context.

H12: The leader's commitment to organisational change (CHNG) mediates the relationship between concern for stakeholder relationships (STK) and concern for financial performance (FIN) in the Sri Lankan organisational context.

H13: The leader's commitment to organisational change (CHNG) mediates the relationship between long-term decision making (LONG) and excellent leadership (EXL) in the Sri Lankan organisational context.

H14: The leader's commitment to organisational change (CHNG) mediates the relationship between long-term decision making (LONG) and concern for social and environmental sustainability (ENV) in the Sri Lankan organisational context.

H15: The leader's commitment to organisational change (CHNG) mediates the relationship between long-term decision making (LONG) and concern for financial performance (FIN) in the Sri Lankan organisational context.

H16: The leader's commitment to organisational change (CHNG) mediates the relationship between employee engagement (EMP) and excellent leadership (EXL) in the Sri Lankan organisational context.

H17: The leader's commitment to organisational change (CHNG) mediates the relationship between employee engagement (EMP) and concern for social and environmental sustainability (ENV) in the Sri Lankan organisational context.

H18: The leader's commitment to organisational change (CHNG) mediates the relationship between employee engagement (EMP) and concern for financial performance (FIN) in the Sri Lankan organisational context.

\section{Appendix C}

\section{1) Exploratory factor analysis solutions for excellent leader (EXL)}

\begin{tabular}{|c|c|c|c|c|}
\hline Item label & Statement & Factor loading & Cronbach's alpha & $\%$ variance \\
\hline EXL07 & Motivate employees & 0.774 & 0.892 & $51.2 \%$ \\
\hline EXL08 & Organise work time effectively & 0.770 & & \\
\hline EXL05 & Have confidence in dealing with work and with people & 0.762 & & \\
\hline EXL06 & Listen when employees want to say something & 0.730 & & \\
\hline EXL02 & Create a sense of purpose and enthusiasm in the workplace & 0.695 & & \\
\hline EXL10 & Have a strategic vision for the organisation & 0.638 & & \\
\hline EXL01 & Continue to learn how to improve performance & 0.632 & & \\
\hline EXL04 & Give recognition for good work & 0.607 & & \\
\hline EXL03 & Develop strategies to gain a competitive edge in the industry & 0.588 & & \\
\hline EXL09 & Be honest & 0.542 & & \\
\hline
\end{tabular}

\section{2) Exploratory factor analysis solutions for concern for social and environmental sustainability (ENV)}

\begin{tabular}{|c|c|c|c|c|}
\hline Item label & Statement & Factor loading & Cronbach's alpha & \% variance \\
\hline ENV7 & Show concern for sustainability issues & 0.811 & 0.910 & $53.57 \%$ \\
\hline ENV6 & Engage in work that makes your community a better place & 0.796 & & \\
\hline ENV8 & Be environmentally responsible & 0.778 & & \\
\hline ENV10 & Identify the impact of your actions on the natural environment & 0.764 & & \\
\hline ENV3 & Promote staff welfare and development & 0.741 & & \\
\hline ENV2 & Be socially responsible & 0.710 & & \\
\hline ENV11 & Continuously learn how to protect the environment & 0.691 & & \\
\hline ENV4 & Establish a friendly working environment & 0.668 & & \\
\hline ENV9 & Encourage recycling of items and materials in your department & 0.629 & & \\
\hline ENV5 & Work as a volunteer in your community & 0.554 & & \\
\hline ENV1 & Be sensitive to people of different backgrounds & 0.505 & & \\
\hline
\end{tabular}

\section{3) Exploratory factor analysis solutions for concern for financial performance of the firm (FIN)}

\begin{tabular}{|c|c|c|c|c|}
\hline Item label & Statement & Factor loading & Cronbach's alpha & $\%$ variance \\
\hline FIN4 & Ensure maximum returns to investors & 0.901 & 0.874 & $73.62 \%$ \\
\hline FIN2 & Achieve financial targets & 0.858 & & \\
\hline FIN3 & Focus on maximising productivity & 0.789 & & \\
\hline FIN1 & Understand potential financial impacts of every decision & 0.673 & & \\
\hline
\end{tabular}


4) Exploratory factor analysis solutions for leaders' commitment to change (CHNG)

\begin{tabular}{llll}
\hline Item label & Statement & Factor loading & Cronbach's alpha \\
\hline CHNG19 & Think frequently about the practice of management & 0.778 & 0.885 \\
CHNG20 & Try different approaches to management & 0.755 & $50 \%$ \\
CHNG15 & Keep up-to-date on management literature & 0.717 \\
CHNG16 & Look for and use the positive aspects of other cultures & 0.715 \\
CHNG14 & Have formal management training & 0.665 \\
CHNG13 & Have a multicultural orientation and approach & 0.649 \\
CHNG12 & Foster an international perspective in the organisation & 0.635 \\
CHNG9 & Be skilled in work-related technology & 0.603 \\
CHNG6 & Be knowledgeable about work of the industry & 0.552 \\
CHNG3 & Be competitive & 0.528 \\
\hline
\end{tabular}

\section{5) Exploratory factor analysis solutions for manager's ethical behaviour (SUSTHINK)}

\begin{tabular}{|c|c|c|c|c|}
\hline Item label & Statement & Factor loadings & Cronbach's alpha & $\%$ variance \\
\hline SUS14 & Speak clearly and concisely & 0.750 & 0.886 & $53.92 \%$ \\
\hline SUS5 & Cope with pressures of work & 0.710 & & \\
\hline SUS12 & Select work wisely to avoid overload & 0.662 & & \\
\hline SUS2 & Accept responsibility for mistakes & 0.659 & & \\
\hline SUS13 & Share power & 0.654 & & \\
\hline SUS4 & Choose management ethics before self or the organization & 0.638 & & \\
\hline SUS15 & Think about the specific details of any particular problem & 0.630 & & \\
\hline SUS1 & Be dependent and trustworthy & 0.607 & & \\
\hline SUS9 & Have a sense of humour & 0.585 & & \\
\hline SUS16 & Treat most people as if they were trustworthy and honest & 0.584 & & \\
\hline SUS19 & Write clearly and concisely & 0.577 & & \\
\hline SUS8 & $\begin{array}{l}\text { Follow what is morally right }- \text { not what is right for self or the } \\
\text { organisation }\end{array}$ & 0.508 & & \\
\hline
\end{tabular}

\section{6) Exploratory factor analysis solutions for stakeholder relationships (STK)}

\begin{tabular}{lllll}
\hline Item label & Statement & Factor loading & Cronbach's alpha & \% variance \\
\hline STK9 & Respect the self-esteem of others & 0.789 & 0.875 & $57.34 \%$ \\
STK2 & Act as a member of a team & 0.760 & & \\
STK4 & Be skilled in public relations & 0.749 & & \\
STK8 & Negotiate with various professionals and interest groups & 0.728 & \\
STK10 & Respond to expectations of consumers & 0.719 & \\
STK3 & Be consistent in dealing with people & 0.616 & \\
STK7 & Listen to the advice of others & 0.590 & \\
\hline
\end{tabular}

7) Exploratory factor analysis solutions for long-term-oriented decision-making (LONG)

\begin{tabular}{llll}
\hline Item label & Statement & Factor loading & Cronbach's alpha \\
\hline LONG16 & Understand and analyse complex problems & 0.819 & 0.873 \\
LONG15 & Think about what may happen in the future & 0.727 & \\
LONG14 & Think about the general implications of any problem & 0.711 \\
LONG2 & Be logical in solving problems & 0.662 \\
LONG17 & Use economic indicators for planning purposes & 0.623 \\
LONG1 & Be consistent in making decisions & 0.617 \\
LONG4 & Be prepared to compromise on important work issues & 0.613 \\
LONG6 & Focus on the task-in-hand & 0.593 \\
LONG5 & Deal with work problems openly and honestly & 0.566 \\
\hline
\end{tabular}

8) Exploratory factor analysis solutions for employee engagement (EMP)

\begin{tabular}{llll}
\hline Item label & Statement & Factor loading & Cronbach's alpha \\
\hline EMP9 & Support decisions made jointly by others & 0.768 & 0.862 \\
EMP7 & Delegate & 0.709 & \\
EMP2 & Allow subordinates authority and autonomy & 0.705 \\
EMP10 & Trust those to whom work is delegated & 0.691 \\
EMP6 & Consider suggestions made by employees & 0.679 & \\
EMP1 & Allow other people time to do things & 0.668 & \\
EMP8 & Make allowances for emotional pressure on staff at work & 0.608 & \\
\hline
\end{tabular}




\section{Appendix D}

Summary of the exploratory factor analysis (EFA) results

\begin{tabular}{|c|c|c|c|c|c|c|}
\hline $\begin{array}{l}\text { EFA } \\
\text { number }\end{array}$ & Construct & $\begin{array}{l}\text { Original } \\
\text { statements }\end{array}$ & $\begin{array}{l}\text { Statements } \\
\text { removed }\end{array}$ & $\begin{array}{l}\text { Statements retained } \\
\text { after EFA }\end{array}$ & $\begin{array}{l}\text { Cronbach's } \\
\text { alpha value }\end{array}$ & $\begin{array}{l}\% \text { variance } \\
\text { explained }\end{array}$ \\
\hline \multicolumn{7}{|c|}{ Dependent variables (sustainability leadership) } \\
\hline 1 & $\begin{array}{l}\text { Excellent leader } \\
(\mathrm{EXL})\end{array}$ & EXL $1-10$ & None & EXL 1 to 10 & 0.892 & $51.2 \%$ \\
\hline 2 & $\begin{array}{l}\text { Concern for social and } \\
\text { environmental } \\
\text { sustainability (ENV) }\end{array}$ & ENV 1-11 & None & ENV 1 to 11 & 0.910 & $53.57 \%$ \\
\hline 3 & $\begin{array}{l}\text { Concern for financial } \\
\text { performance of the } \\
\text { firm (FIN) }\end{array}$ & FIN 1-4 & None & FIN 1 to 4 & 0.874 & $73.62 \%$ \\
\hline \multicolumn{7}{|c|}{ Mediating variables } \\
\hline 4 & $\begin{array}{l}\text { Leader's commitment } \\
\text { to change (CHNG) }\end{array}$ & CHNG 1-22 & $\begin{array}{l}\text { CHNG } 1,2,4,5,7, \\
8,10,11,17,18, \\
21,22\end{array}$ & $\begin{array}{l}\text { CHNG } 3,6,9,12, \\
13,14,15,16,19,20\end{array}$ & 0.885 & $50.00 \%$ \\
\hline 5 & $\begin{array}{l}\text { Manager's ethical } \\
\text { behaviour } \\
\text { (SUSTHINK) }\end{array}$ & SUS 1-19 & $\begin{array}{l}\text { SUS } 3,6,7,10,11 \text {, } \\
17,18\end{array}$ & $\begin{array}{l}\text { SUS } 1,2,4,5,8,9 \\
12,13,14,15,16,19\end{array}$ & 0.886 & $53.92 \%$ \\
\hline \multicolumn{7}{|c|}{ Independent variables (leadership dimensions) } \\
\hline 6 & $\begin{array}{l}\text { Stakeholder } \\
\text { relationships (STK) }\end{array}$ & STK 1-11 & STK $1,5,6,11$ & $\begin{array}{l}\text { STK } 2,3,4,7,8,9, \\
10\end{array}$ & 0.875 & $57.34 \%$ \\
\hline 7 & $\begin{array}{l}\text { Long-term } \\
\text { decision-making } \\
\text { (LONG) }\end{array}$ & LONG 1-17 & $\begin{array}{l}\text { LONG } 3,7,8,9, \\
10,11,12,13\end{array}$ & $\begin{array}{l}1,2,4,5,6,14,15 \\
16,17\end{array}$ & 0.873 & $50.00 \%$ \\
\hline 8 & $\begin{array}{l}\text { Employee engagement } \\
\text { (EMP) }\end{array}$ & EMP $1-11$ & EMP $3,4,5,11$ & $\begin{array}{l}\text { EMP } 1,2,6,7,8,9 \text {, } \\
10\end{array}$ & 0.862 & $55.14 \%$ \\
\hline Total & & 105 & 35 & 70 & & \\
\hline
\end{tabular}

\section{Appendix E}

Summary of the model fit statistics for confirmatory factor analysis (CFA)

\begin{tabular}{|c|c|c|c|c|c|c|c|c|c|c|}
\hline $\begin{array}{l}\text { CFA number and } \\
\text { construct name }\end{array}$ & $\begin{array}{l}\text { Chi-square } \\
\text { (df) }\end{array}$ & $\begin{array}{l}\text { Boot-strap } \\
\text { p-value }\end{array}$ & CMIN/df & CFI & GFI & AGFI & TLI & RMSEA & RMR & SRMR \\
\hline \multicolumn{11}{|c|}{ Dependent variable(s) } \\
\hline CFA1 (EXL) & $38.219(14)$ & $0.075(\mathrm{~ns})$ & 2.73 & 0.980 & 0.976 & 0.953 & 0.971 & 0.06 & 0.016 & 0.029 \\
\hline CFA2 (ENV) & $2.835(5)$ & $1.000(\mathrm{~ns})$ & 0.567 & 1.000 & 0.998 & 0.993 & 1.000 & 0.000 & 0.005 & 0.0074 \\
\hline CFA3 (FIN) & $1.962(1)$ & $1.000(\mathrm{~ns})$ & 1.962 & 0.998 & 0.997 & 0.984 & 0.994 & 0.045 & 0.013 & 0.000 \\
\hline \multicolumn{11}{|c|}{ Mediating variable(s) } \\
\hline CFA5 & $25.083(9)$ & 0.088 (ns) & 2.787 & 0.975 & 0.983 & 0.960 & 0.958 & 0.061 & 0.022 & 0.0315 \\
\hline \multicolumn{11}{|c|}{ (ETHICS-SUSTHINK) } \\
\hline \multicolumn{11}{|c|}{ Independent variable(s) } \\
\hline CFA6 (STK) & $17.466(5)$ & $0.078(\mathrm{~ns})$ & 3.493 & 0.981 & 0.985 & 0.955 & 0.963 & 0.072 & 0.015 & 0.028 \\
\hline CFA7 (LONG) & $36.45(14)$ & $0.06(\mathrm{~ns})$ & 2.604 & 0.978 & 0.978 & 0.956 & 0.967 & 0.058 & 0.018 & 0.0304 \\
\hline CFA8 (EMP) & $7.447(5)$ & $0.784(\mathrm{~ns})$ & 1.489 & 0.996 & 0.994 & 0.982 & 0.992 & 0.032 & 0.011 & 0.0173 \\
\hline
\end{tabular}




\section{Appendix F}

1) Final measurement model for sustainability leadership (dependent variables)

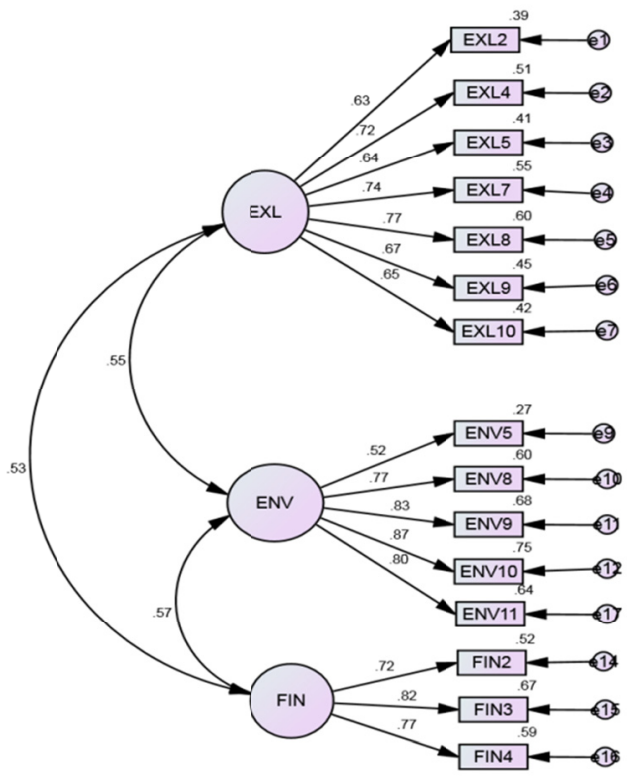

Note. Chi-square $=156.371(\mathrm{df}=87)$, p-value (bootstrap p-value $95 \% \mathrm{CT}$ with 1,000 samples $)=0.000(0.077), \mathrm{CMIN} / \mathrm{DF}=1.797, \mathrm{CFI}=0.979$, $\mathrm{GFI}=0.958, \mathrm{AGFI}=0.942, \mathrm{TLI}=0.974, \mathrm{RMSEA}=0.041, \mathrm{RMR}=0.021, \mathrm{SRMR}=0.036$

Validity, reliability and correlation of the measurement model for sustainability leadership (dependent variables)

\begin{tabular}{lllll}
\hline Construct & Cronbach's alpha & EXL & ENV & FIN \\
\hline EXL & 0.863 & $\mathbf{0 . 4 7 6}$ & & \\
ENV & 0.868 & 0.303 & $\mathbf{0 . 5 9 0}$ & \\
FIN & 0.813 & 0.282 & 0.326 & $\mathbf{0 . 5 9 4}$ \\
\hline
\end{tabular}

Note. All correlations are significant at $\mathrm{p}<0.001$

Diagonal values represent the AVE values of the individual variable.

\section{Summary of measurement model for sustainability leadership (dependent variables)}

\begin{tabular}{|c|c|c|c|c|}
\hline Construct & Statement & Factor loading & Cronbach's alpha & AVE \\
\hline \multirow[t]{7}{*}{ EXL } & Create a sense of purpose and enthusiasm in the work place (EXL2) & 0.626 & 0.863 & 0.476 \\
\hline & Give recognition for good work (EXL4) & 0.716 & & \\
\hline & Have confidence in dealing with work and with people (EXL5) & 0.641 & & \\
\hline & Motivate employees (EXL7) & 0.743 & & \\
\hline & Organise work time effectively (EXL8) & 0.775 & & \\
\hline & Be honest (EXL9) & 0.669 & & \\
\hline & Have a strategic vision for the organisation (EXL10) & 0.647 & & \\
\hline \multirow[t]{5}{*}{ ENV } & Work as a volunteer in your community (ENV 5) & 0.522 & 0.868 & 0.590 \\
\hline & Be environmentally responsible (ENV 8) & 0.775 & & \\
\hline & Encourage recycling of items and materials in your department (ENV 9) & 0.827 & & \\
\hline & Identify the impact of your actions on the natural environment (ENV 10) & 0.868 & & \\
\hline & Continuously learn how to protect the environment (ENV 11) & 0.800 & & \\
\hline \multirow[t]{3}{*}{ FIN } & Achieve financial targets (FIN 2) & 0.724 & 0.813 & 0.594 \\
\hline & Focus on maximising productivity (FIN 3 ) & 0.816 & & \\
\hline & Ensure maximum returns to investors (FIN 4) & 0.770 & & \\
\hline
\end{tabular}




\section{2) Final measurement model for mediating variables}

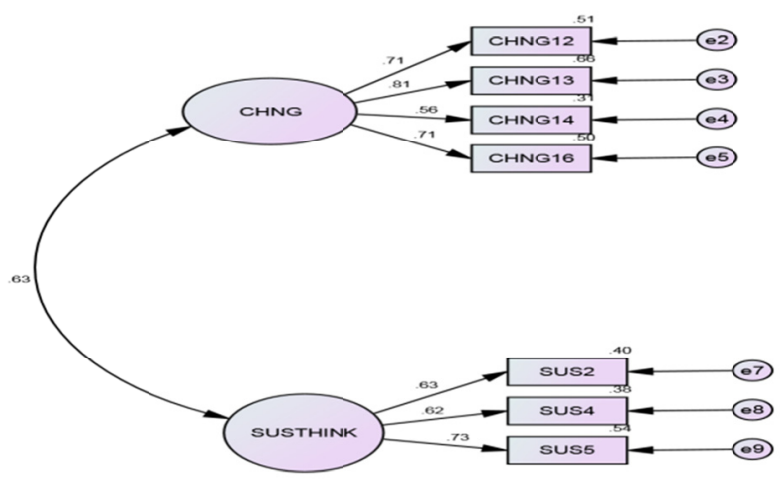

n.b. The AVE value between the two constructs (i.e., 0.468) was greater than the squared correlations between the variables (i.e., 0.397), which confirmed discriminant validity as recommended by Fornell and Larcker (1981)

\section{3) Final measurement model for leadership excellence dimensions (independent variables)}

\begin{tabular}{lllll}
\hline Construct & Statement & Factor loading & Cronbach's alpha & Variance extracted \\
\hline CHNG & $\begin{array}{l}\text { Foster an international perspective in the } \\
\text { organisation (CHNG12) }\end{array}$ & .714 & 0.795 & 0.497 \\
& $\begin{array}{l}\text { Have a multicultural orientation and } \\
\text { approach (CHNG 13) }\end{array}$ & .814 & & \\
& $\begin{array}{l}\text { Have formal management training } \\
\text { (CHNG14) }\end{array}$ & .560 & & \\
& $\begin{array}{l}\text { Look for and use the positive aspects of } \\
\text { other cultures (CHNG16) }\end{array}$ & .708 & 0.693 & 0.439 \\
ETHICS & $\begin{array}{l}\text { Accept responsibility for mistakes (SUS2) } \\
\text { ChUSTHINK) }\end{array}$ & $\begin{array}{l}\text { Choose management ethics before self or the } \\
\text { organisation (SUS4) } \\
\text { Cope with pressures of work (SUS5) }\end{array}$ & .619 & \\
& & & & \\
&
\end{tabular}

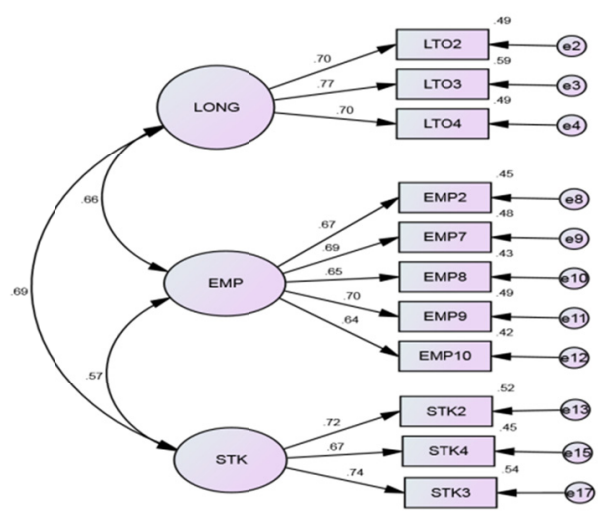




\section{Summary of measurement model for independent variables}

\begin{tabular}{|c|c|c|c|c|}
\hline Construct & Statement & Factor loading & Cronbach's alpha & AVE \\
\hline \multirow[t]{3}{*}{ STK } & Act as a member of a team (STK2) & 0.722 & 0.752 & 0.504 \\
\hline & Be consistent in dealing with people (STK3) & 0.736 & & \\
\hline & Be skilled in public relations (STK4) & 0.671 & & \\
\hline \multirow[t]{3}{*}{ LONG } & Be logical in solving problems (LTO2) & 0.704 & 0.769 & 0.526 \\
\hline & Be objective when dealing with work conflicts (LTO3) & 0.770 & & \\
\hline & Be prepared to compromise on important work issues (LTO4) & 0.699 & & \\
\hline \multirow[t]{5}{*}{ EMP } & Allow subordinates authority and autonomy (EMP2) & 0.670 & 0.803 & 0.452 \\
\hline & Delegate (EMP7) & 0.693 & & \\
\hline & Make allowance for emotional pressure on staff at work (EMP8) & 0.654 & & \\
\hline & Support decisions made jointly by others (EMP9) & 0.699 & & \\
\hline & Trust those to whom work is delegated (EMP10) & 0.644 & & \\
\hline
\end{tabular}

Validity, reliability and correlation of the measurement model for independent variables

\begin{tabular}{lllll}
\hline & Cronbach's alpha & LONG & EMP & STK \\
\hline LONG & 0.769 & $\mathbf{0 . 5 2 6}$ & & \\
EMP & 0.803 & 0.434 & $\mathbf{0 . 4 5 2}$ & \\
STK & 0.752 & 0.482 & 0.329 & $\mathbf{0 . 5 0 4}$ \\
\hline
\end{tabular}

Note. All the correlation values are significant at $\mathrm{p}<0.001$. Diagonal values represent the AVE values of the individual variable.

\section{Appendix G}

Total standardized effect of excellence leadership dimensions on sustainability leadership

\begin{tabular}{ll}
\hline Path & Standardised total effects \\
\hline LONG $\rightarrow$ EXL & $0.118(n s)^{\mathrm{a} / \mathrm{b}}$ \\
$\mathrm{LONG} \rightarrow$ ENV & $0.071(\mathrm{~ns})^{\mathrm{a} / \mathrm{b}}$ \\
$\mathrm{LONG} \rightarrow$ FIN & $0.172(\mathrm{~ns})^{\mathrm{a} / \mathrm{b}}$ \\
$\mathrm{EMP} \rightarrow$ EXL & $0.173(\mathrm{~ns})^{\mathrm{a}}$ \\
& $0.173 * * \mathrm{~b}$ \\
$\mathrm{EMP} \rightarrow$ ENV & $0.221(\mathrm{~ns})^{\mathrm{a}}$ \\
& $0.221 * * \mathrm{~b}$ \\
$\mathrm{EMP} \rightarrow$ FIN & $0.267 * * * \mathrm{a} / \mathrm{b}$ \\
$\mathrm{STK} \rightarrow$ EXL & $0.621(\mathrm{~ns})^{\mathrm{a}}$ \\
& $0.621 * * \mathrm{~b}$ \\
$\mathrm{STK} \rightarrow$ ENV & $0.391 * * * \mathrm{a} / \mathrm{b}$ \\
$\mathrm{STK} \rightarrow$ FIN & $0.270(\mathrm{~ns})^{\mathrm{a}}$ \\
& $0.270 * * \mathrm{~b}$ \\
\hline
\end{tabular}

Note. $. \mathbf{a}=\mathbf{9 9 . 9} \%$ significance level (according to Bonferroni method)

$\mathrm{P}<0.0018=* * *$ and $\mathrm{ns}=$ not significant

$\underline{\mathrm{b}=95 \% \text { significance level }}$

$\mathrm{P}<0.0018=* * *$

$\mathrm{P}<0.01=* *$

$\mathrm{P}<0.05=*$ and $\mathrm{ns}=$ not significant 


\section{Appendix H}

\section{Sustainability leadership structural model with only significant paths}

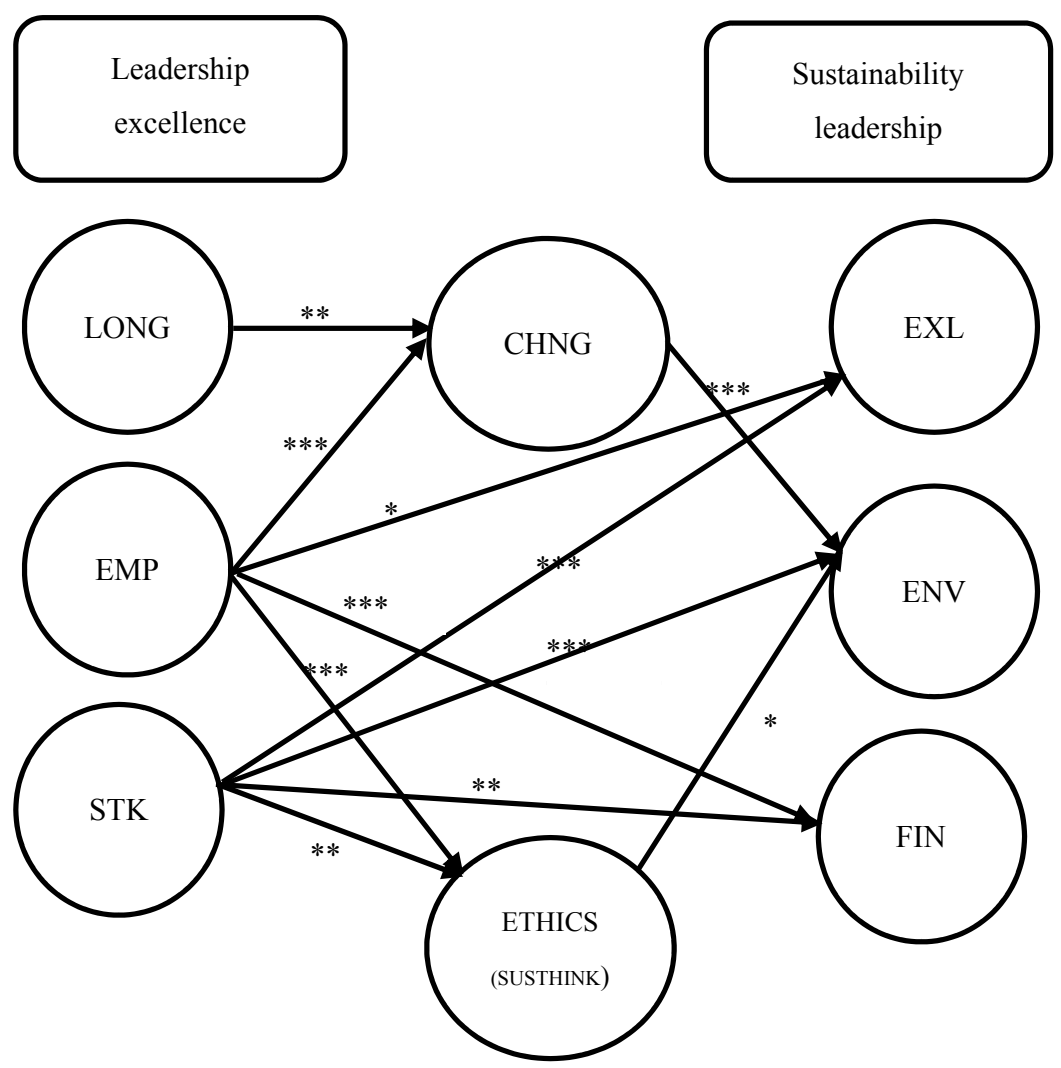

Note. Only significant paths shown with bootstrap p-values, $\mathrm{p}<0.05=*, \mathrm{p}<0.01=* *$ and $\mathrm{p}<0.001=* * *$.

\section{Copyrights}

Copyright for this article is retained by the author, with first publication rights granted to the journal.

This is an open-access article distributed under the terms and conditions of the Creative Commons Attribution license (http://creativecommons.org/licenses/by/4.0/). 